\title{
Between a Rock and Hard Place: Combined Effects of Authentic \\ Leadership, Organizational Identification, and Team Prototypicality on \\ Managerial Prohibitive Voice
}

Lucas Monzani $^{1}$, Michael Knoll ${ }^{2}$, Steffen Giessner ${ }^{3}$, Rolf van Dick ${ }^{4}$, and José María Peiró ${ }^{5}$

Western University (Canada)

Technische Universität Chemnitz, (Germany)

Erasmus Universiteit Rotterdam (The Netherlands)

Goethe-Universität Frankfurt(Germany)

Universidad de Valencia (Spain)

This study was jointly conducted by the research of Instituto de Investigación en Psicología de los RRHH, del Desarrollo Organizacional y de la Calidad de Vida Laboral (IDOCAL) of the Universidad de Valencia (Spain) and the Center for Leadership and Behavior in Organizations (CLBO) at Goethe-Universität Frankfurt. An early version of this work was presented at the $74^{\text {th }}$ Academy of Management annual meeting. This study was funded by following research grants: ECD/3628/2011 available at BOE-A-2012-680; CICYT, PSI2012-36557 \& PROMETEO $2012 / 048$

Correspondence concerning this article should be addressed to Lucas Monzani. Western University. Ivey Business School. 1255 Western road, N6G 0N1 London, Ontario (Canada). E-mail: lmonzani@ivey.ca 


\section{How to cite this article:}

Monzani, L., Knoll, M., Giessner, S., van Dick, R., \& Peiró, J. M. (2018). Between a rock and hard place: Combined effects of authentic leadership, organizational identification, and team prototypicality on managerial prohibitive voice. The Spanish Journal of Psychology, 21. eXX. Doi:XXXXXXXXXX 


\begin{abstract}
Managers are installed by the organization's stakeholders and shareholders to increase the organization's value; at the same time, they depend on their subordinates' acceptance to fulfill this leadership role. If the interest of the organization collides with the interest of their team, some managers act in the interest of their followers accepting potential disadvantages for their organizations and/or external stakeholders. In two experimental studies comprised mainly of German $(N=111)$ and US $(N=323)$ managers, we examined combined effects of authentic leadership, organizational identification, and self-perceived team prototypicality on managerial integrity operationalized as expressing work-related concerns to prevent organizations from harm (i.e., managerial voice). Our results show direct effects of authentic leadership and organizational identification on voice behavior across both studies. Furthermore, organizational identification increased voice for managers' low in authentic leadership pointing at a compensation effect. Finally, leader team prototypicality decreased the effect of identification on voice for managers high in authentic leadership but increased voice for managers low in authentic leadership, but only if these managers identified with their organization. In sum, our findings complement prior research that focused mainly on safety and instrumentality concerns by emphasizing the relevance of self-related antecedents of managerial voice.
\end{abstract}

Keywords: authentic leadership, managerial voice, organizational identification, team prototypicality 
One year before the 1995 Rugby world cup, Nelson Mandela faced a dilemmatic situation. The executive board of South's Africa national sports committee had voted to ban the Springbook's name, emblems, and colors. At that time, the Springboks represented the white South African minority, and more importantly apartheid. Mandela realized, however, that engaging in such acts of "petty revenge" as he termed it, would further alienate the white minority, and confirm their fears against the now ruling black majority. Mandela also knew that the white minority controlled the South African police, its army, and its major industries, three major strategic resources for the long-term viability of South Africa (Civilian and National Security, Job Creation). In the face of such a dilemma, Mandela decided to voice his concerns to the national sports committee and confronted them by asking for a vote to restore the Springbook's name, emblems, and colors. As noted by his advisors, this was a risky move, as Mandela was political capital and his future as leader of South-Africa to defend the interests of those who imprisoned him and many others of his political base. This brief example illustrates that implementing ethical standards at work is difficult for managers, in particular when the interests of the organization and its members are not clearly aligned (Joosten, van Dijke, van Hiel, \& De Cremer, 2014; Kennedy \& Anderson, 2017).

Each day, managers make a significant number of decisions in a way that secures and enlarges their own, their followers', and their organizations' performance and well-being. Besides, managers need to monitor their own and their followers' behavior to maintain their status as leaders (DeRue \& Ashford, 2010; van Vugt, Hogan, \& Kaiser, 2008). Installed by the organization's stakeholders and shareholders, managers have the task of increasing the organization's value (Mintzberg, 1993), and yet depend on subordinates' acceptance of their leadership (Hollander \& Julian, 1967). This conundrum leaves managers "between a rock and a hard place" as soon as the interest of the organization collides with the interests of the teams they manage. 
In dilemmatic situations, some managers choose to sacrifice the good of the organization (and tolerate harm for individual employees and/or external stakeholders) in favor of particular interest groups within it, such as the teams they lead (Moschandreas, 1997; Murtha, Challagalla, \& Kohli, 2011). Other managers may put the interests of the organization before the interests of their teams by engaging in behaviors such as prohibitive voice and principled dissent (Graham, 1986; Liang, Farh, \& Farh, 2012). Making such difficult decisions and communicating them forthrightly to the respective stakeholders, is a facet of managerial integrity (Audi \& Murphy, 2006) that is critical to prevent organizations from harm. However, given that might lead even good people to cross ethical boundaries (Moore \& Gino, 2013), those who install managers (e.g., board members, top-management teams), but also those who depend on managers to ensure the sustainable success of their organization (e.g., shareholders, employees) should know about the factors that drive managers to express work-related concerns, and thus prevent harm to their organizations. The present research aims at enriching this knowledge, by unpacking the key drivers of managerial voice.

Cases of companies' decline caused by managers who failed to correct unethical practices due to giving preference to utilitarian and hedonistic motives (e.g., Dick Fuld at Lehman Brothers; Claxton, Owen, \& Sadler-Smith, 2013) indicate that the personal short-term benefits for the manager of withholding critical views, often outweigh their concern about the adverse effects that withholding voice might have for their organizations. Besides, corporate culture sometimes (implicitly) encourages going along instead of challenging the status quo (Moore \& Gino, 2013; van Dyne, Ang, \& Botero, 2003). These reasons question the sufficiency of the dominating approach to explaining employees' voice behavior, which uses individuals' tendency to weigh potential costs (e.g., becoming a victim of retaliation or threatening relationships) and benefits of speaking up (e.g., process improvements) with their expectation about whether speaking up will make a difference (Morrison, 2011). 
More recent approaches emphasize the pivotal role of the manager's self-concept to understand the implementation of ethical conduct (Gardner, Avolio, Luthans, May, \& Walumbwa, 2005; Kennedy \& Anderson, 2017; Palanski \& Yammarino, 2009; Shamir \& Eilam, 2005). Drawing from humanistic motivational theories such as Organismic Integration Theory, a sub-theory of Self-determination theory (Gagné \& Deci, 2005; Ryan \& Deci, 2000), these approaches embrace the assumption that managers - like all individuals - "have natural, innate, and constructive tendencies to develop an ever more elaborated and unified sense of self" (Ryan \& Deci, 2002, p. 5). Their desire "to forge interconnections among aspects of their own psyches as well as with other individuals and groups in their social worlds" (Ryan \& Deci, 2002, p. 5) affects managers' ongoing transactions with their environment and thus might motivate their choices in dilemmatic situations (Kernis, 2003; Shamir, 1991). In two experimental online studies using German and US samples comprising mainly managers, we examine interactive effects of three identity-related leader characteristics on managerial integrity: Authentic leadership, organizational identification, and self-perceived team prototypicality.

At work, individuals need to perform many activities that are not intrinsically motivated (i.e., done out of interest and inherent satisfaction; Gagne \& Deci, 2005). Organismic Integration Theory (Ryan \& Deci, 2002) proposes that, while many behaviors have to be extrinsically motivated, they are not necessarily forced upon employees or in opposition to the individual's self. Instead of contrasting extrinsic and intrinsic motivation, Organismic Integration Theory proposes a continuum ranging from nonself-determined to self-determined behaviors (Ryan \& Deci, 2000). Extrinsically motivated behaviors can achieve a high degree of self-determination if the employee can internalize the activities' initially external regulation. Identification is one example of internalization that occurs when an employee values a behavioral goal and accepts the behavior that is needed to perform a task as personally 
important. An even higher degree in perceived self-determination is achieved through integrated regulation. Integrated regulation occurs "when identifications have been evaluated and brought into congruence with the personally endorsed values, goals, and needs that are already part of the self" (Ryan \& Deci, 2002, p. 18). Gardner and colleagues (2005) proposed that an authentic leadership style reflects such integrated behavior in a leadership role. Authentic leadership has been linked to managerial integrity because individual differences in self-referent processes tend to foster positive practices in the workplace (Gardner et al., 2005; Gardner, Cogliser, Davis, \& Dickens, 2011).

Although desirable, not all individuals who are expected to execute managerial roles may embody the virtues associated with authentic leaders (e.g., Integrity and Courage; Crossan, Byrne, Seijts, Reno, Monzani, \& Gandz, 2017). Moreover, the goals and values of authentic leaders and organizations might not necessarily overlap (Algera \& Lips-Wiersma, 2012). Thus, extending our understanding about factors that link leaders' values and goals to the organization and that may act as substitutes for desirable leader characteristics could broaden the scope for those concerned with managerial integrity and voice in particular. A first contribution of the present work is to find potential substitutes for authentic leadership as drivers of voice. Drawing on Organismic Integration Theory, we propose that organizational identification, understood as the perception of belongingness to the organization (Ashforth \& Mael, 1989), as a potential substitute. Organismic Integration Theory proposes that identified regulations are - after integrated regulation - the form of external regulation that is most internally motivated. Drawing on the social identity perspective of organizational leadership, we anticipate that identification with a group will increase the leader's group-oriented behavior (Haslam, Reicher, \& Platow, 2011; van Dick \& Kerschreiter, 2016; van Knippenberg \& Hogg, 2003).

As a second candidate for substituting for authentic leadership, we examine leaders' 
self-perceived team prototypicality (van Knippenberg, 2011). Organismic Integration Theory proposes that introjected regulations are - after integrated regulation and regulation based on identification - the third form of internalizing externally regulated behaviors. The motivating effect of introjected regulations is focused on gaining the approval of others (Ryan \& Deci, 2000). Because leaders usually belong to more than one group (e.g., their organization and the teams they lead), acting to the benefit of one group might interfere with the goals of another. In consequence, to better understand managerial behavior in such dilemmatic situations, we examine how self-perceived team prototypicality (i.e., a manager's self-perceived similarity to the prototype of his or her team; Giessner, van Knippenberg, van Ginkel, \& Sleebos, 2013) may influence the effect that organizational identification has on the authentic leadership-voice relation. Self-perceived team prototypicality (further referred in this study as "team prototypicality") increases the salience of a manager's role identity as a team leader (Stryker, 1980), and thus might drive them to favor the interest of their team at the disadvantage of their organization. We propose that self-perceived leader's team prototypicality moderates the impact of organizational identification and authentic leadership by decreasing the direct effect that organizational identification has on prohibitive voice and by influencing the combined effect of authentic leadership and organizational identification on voice. Figure 1 summarizes the proposed direct and interactive relationships between the three identity related constructs on managers' prohibitive voice.

\section{$<$ Insert Figure 1 Here >}

\section{Theoretical Background}

Our research focuses on the direct and combined effects of three identity-related constructs - authentic leadership, the leader's organizational identification, and the leader's team prototypicality - on managers' prohibitive voice (Liang et al., 2012). Prohibitive voice matters for organizations, as it raises awareness of previously undetected problems that need 
to be resolved to prevent the organization and its stakeholders from harm (van Dyne, Cummings, \& Parks, 1995). Notably, prohibitive voice is usually perceived with suspicion than other forms of extra-role behavior (e.g., helping, sportsmanship) and even forms of voice that aim at improving existing work practices and procedures (e.g., promotive voice; Burris, 2012; van Dyne et al., 1995). These bleak prospects, be they based on experience or implicit assumptions, are a central factor for why employees often withhold their critical views at work (Detert \& Edmondson, 2011; Morrison \& Milliken, 2000).

Aiming at finding ways to foster prohibitive voice (further referred as voice in this study), extant research focused on non-managerial employees, treating managers as those who facilitate or inhibit their subordinates' voice (Detert \& Burris, 2007; Fast, Burris, \& Bartel, 2014). Managerial voice received less attention than employee voice, in part because their position's power makes managers less vulnerable to the potential backlashes of voice and allows them to implement their ideas more quickly (Ashford, Sutcliffe, \& Christianson, 2009). Despite their greater discretion, it would be unwise for managers to decide on voice in a lighthearted manner, especially if such behavior could be to the disadvantage of their close followers (e.g., their team members). To fulfill their task as leaders, managers depend on followers granting them leadership and acting on their behalf (DeRue \& Ashford, 2010; Hollander \& Julian, 1969). Consequently, in their decision to mention critical issues, managers need to make trade-offs between the benefit of the organization and the interest of the team they lead. To maintain high ethical standards and avoid the negative consequences of unethical practices (e.g., corruption), those who appoint managers need to know about factors that influence whether or not managers withstand temptations to put self-interests or the interests of groups within or outside the organization before of the interests of the organization (Sturm \& Monzani, 2017). 


\section{Authentic leadership}

Managerial integrity (Audi \& Murphy, 2006) requires personal characteristics such as honesty, consistency of internal values and action, and moral courage (Blasi, 1980; Palanski \& Yammarino, 2009). The leadership literature describes managers who embody such characteristics as authentic leaders (May, Chan, Hodges, \& Avolio, 2003). Authentic leaders are (a) self-aware, (b) relationally transparent, (c) process information in a balanced way, and (d) act according to an internalized moral perspective (Gardner et al., 2005; Walumbwa, Avolio, Gardner, Wernsing, \& Peterson, 2008). The self-awareness dimension denotes high levels of self-clarity (e.g., regarding one's values and motives) and the striving to develop an integrated view of one's identity, meaning that authentic leaders do not suppress aspects of their selves when evaluating situations or forming moral judgments. The other three dimensions express the relational, cognitive, and affective mechanisms that evidence an integrated behavior within a leadership role (Hernández, Eberly, Avolio, \& Johnson, 2011).

Ethical failure often occurs when managers suppress aspects of their selves and then fail to notice that situations are morally questionable, or when managers lack the self-regulatory strength or willpower to implement ethical conduct (Bazerman \& Gino, 2012; Trevino, Weaver \& Reynolds, 2006). Managerial integrity has been associated with authentic leaders as their holistic self-awareness makes them less vulnerable to morally disengage and take moral shortcuts, and their value-based self-regulation makes them implement ethical conduct even against external pressures (Knoll, Lord, Petersen, \& Weigelt, 2016). Although numerous conceptual articles suggest a link between authentic leadership and managerial integrity (e.g., May et al., 2003), empirical evidence is still scarce (Leroy, Palanski, \& Simons, 2012). Moreover, some scholars question whether such a link is essential to the idea of authentic leadership at all (e.g., Algera \& Lips-Wiersma, 2012).

Although we do not propose a relationship between authentic leadership and morality 
in general, we posit that due to their characteristics, authentic leaders are more likely to withstand external pressures and temptations to act in unethical ways. Specifically, we propose that in dilemmatic situations, authentic leaders will express their concerns on issues that might harm the organization even if doing so is to their disadvantage, or to the detriment of their team which might eventually weaken their position's strength within their team. Although research on the link between authentic leadership and manager voice is scarce, research on trait authenticity supports our prediction. For example, Knoll, Meyer, Kroemer, and Schröder-Abé (2015) found a positive relationship between trait authenticity and moral courage in a study with university students and Knoll and van Dick (2013) showed that trait authenticity was negatively related to employee silence. Further, prior studies found that authentic leadership predicts employee voice (Hsuing, 2012) and loyalty (Monzani, Ripoll \& Peiró, 2014), and negatively predicts employee's intentions of either neglecting the problem or exiting the organization (Monzani, Braun, \& van Dick, 2016). Given that managers are employees' themselves, we expect that the aforementioned processes apply to managerial voice and expect:

Hypothesis 1: Authentic leadership positively relates to voice in dilemmatic situations.

\section{The moderating role of social identity processes: Identification and prototypicality}

Reliance on leaders' characteristics might be dangerous, as only a few individuals that are required to fulfill leadership roles in organizations may embody the qualities associated with authentic leadership (Diddams \& Chang, 2012). Furthermore, even if authentic leaders display consistency between their values and their actions, is not self-evident that an authentic leader's values will be in line with the values of the organization they lead (Algera \& LipsWiersma, 2012). Thus, whether the virtues associated with authentic leaders manifest in voice that prevents their organization from harm (voice) should depend on whether leaders deem the 
organization as a relevant part of their identity.

Social identity approaches to leadership (Haslam et al., 2011; van Knippenberg \& Hogg, 2003; van Dick et al., 2018) suggest that (a) the degree to which leaders define their identity with reference to the groups they belong to, and (b) the extent to which leaders perceive themselves as embodying these groups also influences manager behavior. To extend the scope of possible ways to increase managerial integrity beyond a leader's individual characteristics, but also to examine how aspects of the leaders' personal and social identity may interact, we examine the influence of organizational identification, and leaders' team prototypicality as predictors of voice and as moderators of the authentic leadership-voice relationship.

\section{Organizational identification}

We expect that managers' will more likely engage in voice aimed at preventing the organization from harm if they perceive a sense of belongingness to their organization. Prior research supports a relationship between organizational identification and extra-role behaviors (van Dick, Grojean, Christ, \& Wieseke, 2006) considering that voice is a manifestation of challenging extra-role behavior (van Dyne et al., 1995). More precisely, organizational identification relates to the expression of discontent with group norms (Crane \& Platow, 2010; Packer, 2008), as well as employee voice (Tangirala \& Ramanujam, 2008) and silence (Knoll \& van Dick, 2013). Meta-analyses recently supported that organizational identification relates to potential antecedents of voice such as job involvement (Lee, Park, \& Koo, 2015) and voice behavior (Chamberlin, Newton, \& Lepine, 2017). Thus, we expect organizational identification to be directly related to voice because identification links the benefits of the organization to the benefits of the manager. Congruence between self and organizational goals, methods, and values should give authentic leaders a direction for consistent self-expression, and thus should increase their tendency to voice concerns.

We furthermore propose that organizational identification functions as a moderator 
between authentic leadership and voice. More specifically, we suggest that identification functions as a substitute for authentic leadership and increase voice for managers who score low on authentic leadership (further referred in the text as inauthentic managers). Inauthentic managers are not too motivated to stick to their values and beliefs if this leads to personal disadvantages (which are likely if they speak up to the detriment of their team). Consequently, they may be tempted to remain silent, even if their silence harms their organization. Organizational identification could supplement this gap in managerial motivation because protecting the organization from harm is a means of maintaining a valued aspect of their (social) self. In line with this reasoning but focusing on non-managerial employees, Knoll and van Dick (2013) found that the (negative) relationship between trait authenticity and silence was stronger for employees high in organizational identification.

Hypothesis 2a: Organizational identification is positively related to voice

Hypothesis 2b: Organizational identification moderates the relationship between authentic leadership and voice, so that this relation will be stronger for highly identified managers

\section{Self-perceived leader team prototypicality}

When at work, the organization is not the only group to which managers belong. For example, most managers lead teams and thus to be effective leaders they should see themselves (and be seen by others) as part of these teams (Haslam et al., 2011; van Knippenberg, 2003). Prototypical managers, who are aware of this pertinent status, usually want their team to flourish, and they know that their followers rely on them to nurture the team's prosperity. In dilemmatic situations where organizational and team interests collide, managerial integrity manifests in the moral courage to "have the backbone to make difficult decisions (...) and communicate them forthrightly to lower level employees" (Audi \& Murphy, 2006, p. 15). 
Whereas identification with the organization should increase a manager's tendency to engage in voice, self-categorization processes such as perceiving oneself as similar to the group prototype (i.e., self-perceived team prototypicality; van Knippenberg \& Hogg, 2003) might interfere with this impetus.

We expect leaders' team prototypicality to moderate the relationship between organizational identification and voice because noticing that one is prototypical increases the salience of being a team leader. Thus, this perception motivates to favor the interest of the group to the disadvantage of other larger groups such as the organization, because "selfdefinition as group prototypical implies ascribing group norms and interests to self" (van Knippenberg, 2011). The team members of managers who are highly prototypical usually expect prototypical leaders to take actions to advance the interest of the group (e.g., leaders must be "in-group champions"; Haslam et al., 2011). Such expectations increase a leader's accountability towards the team (Giessner et al., 2013). Consequently, in his summary of the studies available on leaders' self-perceived team prototypicality, van Knippenberg (2011) argues that "self-perceived group prototypicality motivates the kind of attitudes and actions that followers expect group-prototypical leaders to display" (p. 1086). Consequently, we expect:

Hypothesis 3a: A leader's team prototypicality will moderate the relation between organizational identification and voice so that this relation weakens as team prototypicality increases.

The internalized moral perspective dimension of authentic leadership suggests that authentic leaders' behavior follows from their inner values and thus is less influenced by external forces such as situational constraints or temptations (Chan, Hannah, \& Gardner, 2005). However, the self-awareness dimension of authentic leadership suggests that these leaders are sensitive to self-relevant cues from their environment but also cues from their experience of 
the situation (e.g., feelings of guilt, pride, shame). Thus, authentic leaders are motivated to use this self-relevant information to actualize their self-view (Knoll et al., 2015; Eriksen, 2009). Perceiving oneself as similar to the group prototype against which one needs to make a decision creates a conflict that disturbs the chance to express their whole self consistently. This disturbance might make authentic leaders hesitant to implement significant actions. Thus, for authentic managers, the amplifying effect of organizational identification should disappear. Team prototypicality should have a lower influence for inauthentic managers because they are less sensitive to actualize their self-views. Similarly, managers with a strong organizational identification should not let salience effects influence their decision to engage in voice with ease. Considering that, we expect:

Hypothesis 3b: Team prototypicality moderates the relation between authentic leadership, organizational identification, and voice. As team prototypicality increases, the effect of organizational identification on the authentic leadership- voice relation decreases.

\section{Study 1}

\section{Method}

\section{Participants and procedure}

Our sample consisted of 111 managers (43.2\% female) of which $70.3 \%$ were German, $13.5 \%$ from the US and 16.2\% were from other Western European countries who participated in a larger research project examining cross-cultural leadership behavior. At the time of our survey, managers' mean age was 43.42 years $(S D=11.41)$, ranging from 25 to 64 years. Of the participants, $91 \%$ had a permanent work contract; $80 \%$ of the participants worked in the private sector, $20 \%$ worked in the public sector. Several work domains were present in our sample, human resources being the largest (13.4\%), followed by line management (6.7\%) and sales $(4.7 \%)$. The managers had a mean of 32.05 employees $(S D=51.58)$ reporting them. They were recruited from existing contact networks and invited to take part in an online survey that 
included an experimental manipulation of team prototypicality.

After completing their demographic information, the managers rated the frequency of their authentic leadership behaviors. Next, we manipulated team prototypicality (high vs. low) via a short vignette before asking participants to respond to the manipulation check (see van Dick \& Schuh, 2010 for a similar procedure). Then, participants read the scenario (see Appendix A) describing a dilemmatic situation in which a leader has to decide whether to voice their concerns and prevent the organization from harm or remain silent and allow the team to receive a reward for completing a project although the delivered product is flawed. Finally, participants responded to measures assessing their identification with the fictitious organization portrayed in the scenario.

\section{Measures}

Authentic leadership. We used Walumbwa et al., (2008) Authentic Leadership Questionnaire (ALQ), comprising 16 items to measure participants' self-reported frequency of AL behaviors. Sample items are "Seeks feedback to improve interactions with others" (Selfawareness); "Says exactly what he or she means" (relational transparency); "Makes decisions based on his/her core beliefs" (Internalized moral perspective); "Listens carefully to different points of view before coming to conclusions" (Balanced processing of information). All items were rated on 5 -point Likert-type scales, with values ranging from " $1=$ not at all" to " $5=$ frequently, if not always". Given that Walumbwa et al. (2008) define authentic leadership as a higher-order construct, we used the composite scale in our analyses. Cronbach's alpha for the composite scale was .90 .

Organizational identification. We used the following four items from Kreiner and Ashforth (2004) to measure identification with the fictitious company: "When I talk about this organization, I usually say we rather than they", "The organization's successes are my successes", and "When someone praises this organization it feels like a personal compliment". 
All items were rated on 5-point Likert-type scales ranging from " $1=$ strongly disagree" to "5 $=$ strongly agree". Cronbach's alpha was .87 .

Leader team prototypicality was manipulated by showing participants a vignette text and six pie chart figures. Participants were asked to think of themselves as high-level managers in a multinational organization, leading a small team of direct reports. They just received an email with the results of a recent HR internal survey exploring the match between upper (the participant) and middle managers' (their direct reports) understanding of six key elements of their organization (vision, mission, organizational values and culture, strategy, work processes, and career development opportunities). Immediately below, all figures displayed either high (from $65 \%$ to $91 \%$ ) or low (12\% to $32 \%$ ) levels of match to the group prototype, depending on the condition (for a similar approach see Giessner et al., 2013). This manipulation was followed by a manipulation check including the following two items: (1) "I represent what is characteristic about my team" and (2) "I represent what my team has in common". Scale range was from $1=$ "do not agree with at all" to 7 = "fully agree". Cronbach's alpha was .92.

Managerial voice. We used a scenario technique that was based on the EVLN (exit, voice, loyalty, neglect)-model (Hagedoorn, van Yperen, van De Vliert, \& Buunk, 1999) to examine a manager's response to a dilemmatic situation described in a scenario. As managers usually have more options than to voice their concerns or not, we allowed them to choose between four options to provide higher external validity. Moreover, because voice is not the only positively connoted option given, assessing multiple alternatives also reduces social desirable responding. The four response types were evaluated with three items each which were taken from Knoll and van Dick (2013) adaptation of Hagedoorn et al.'s (1999) original measure. All items were rated on a 5-point Likert-type scale with values ranging from " $1=$ not likely" to "5 = very likely". Sample items are "I intend to quit" (exit $\alpha=.91$ ), "I speak about the problem with my supervisory board" (voice $\alpha=.75$ ), "I trust the organization to solve the 
problem without my help" (loyalty $\alpha=.74$ ), "I put less effort into my work than may be expected of me" (neglect $\alpha=.85)$.

\section{Results}

\section{Preliminary analyses and manipulation check}

Because outliers increase error variance and reduce the power of statistical tests (Osborne \& Overbay, 2004), we checked for outliers in boxplot graphs of the voice variable and checked at each regression the OLS regressions residuals, using as exclusion criteria $z>4$. We identified and removed only one severe outlier ${ }^{1}$.

To ensure that our manipulation had the intended effect, we performed an independent sample $t$-test to compare means of participants' perceived prototypicality across conditions. As expected, participants in the high team prototypicality condition $(M=5.23, S E=1.04)$ perceived themselves significantly more prototypical of their teams, $t(1,109)=-11.32, p<$ .0001 , than those in the low team prototypicality condition $(M=2.39, S E=1.56)$.

Similarly, we conducted a confirmatory factor analysis to ensure that items conforming the scales for authentic leadership, organizational identification loaded in fact into their respective latent constructs. Our CFA results show that the five-factor model ( $\mathrm{S}-\mathrm{B} \chi^{2}=195.94$, $\left.p<.5 ; \chi^{2} / \mathrm{DF}=1.42 ; \mathrm{RMSEA}=.06 ; \mathrm{NNFI}=.91 ; \mathrm{CFI}=.93\right)$ fits our data better that the twofactor model $\left(\mathrm{S}-\mathrm{B} \chi^{2}=213.13 ; p<.05 ; \chi^{2} / \mathrm{DF}=1.49 ; \mathrm{RMSEA}=.07 ; \mathrm{NNFI}=.91 ; \mathrm{CFI}=.92\right)$ or the single-factor model $\left(\mathrm{S}-\mathrm{B} \chi^{2}=354.64 ; p<.5 ; \chi^{2} / \mathrm{DF}=2.33 ; \mathrm{RMSEA}=.11 ; \mathrm{NNFI}=.77\right.$; $\mathrm{CFI}=.74)$. Further the S-B scaled corrected $\chi^{2}$ difference test, show that both the 5 -factor model, $\Delta \chi^{2}(14)=129.77, p<.001$, and the two-factor model, $\Delta \chi^{2}(9)=74.16, p<.001$, fitted the data better than the single factor model. This shows that participants understood authentic

${ }^{1}$ While box-plot graphs did not shown outliers, in regression analysis, for voice as dependent variable a case showed a regression residual of $z=-4.56$. For the TP $\mathrm{x}$ OID regression analysis, 4 additional outliers were removed, 3 outliers because Mahobi's distance were significantly higher than the mean value and 1 outlier because its regression residual was $z=-3.87$. 
leadership and organizational identification as two separate constructs. However, there were no substantial fit differences between the 4-dimension model of authentic leadership, and the higher-order model, so using authentic leadership as composite construct in this study is justified by our data.

\section{Hypothesis Testing}

The lower diagonal of Table 1 shows means, standard deviations, and Pearson's bivariate correlations for all variables from Study 1. As can be seen in Table 1, authentic leadership and organizational identification are positively related to voice supporting Hypotheses 1 and 2a. Further supporting our reasoning, authentic leadership and organizational identification were also negatively related to exit, neglect, and loyalty (which represent silence).

\section{<Insert Table 1 Here>}

To examine whether organizational identification moderates the relationship between authentic leadership and Voice (Hypothesis 2b), we performed multiple regression analysis using mean-centered predictor variables (Aiken \& West, 1991) and Voice as the dependent variable. As can be seen in Table 2, authentic leadership and organizational identification were included in the first step and the interaction term in the second step. In line with Hypothesis $2 \mathrm{~b}$, the interaction term was significant, $\beta=-.23 t(3,107)=-3.06, p<.01$.

\section{<Insert Table 2 Here>}

Simple slopes analyses (Aiken \& West, 1991) show a significant slope gradient of organizational identification for managers with low scores on authentic leadership, $\beta=.29, t(1$, $110)=4.50, p<.001$, but not for high levels of authentic leadership, $\beta=.03, t(1,109)=.27, p$ $<.79$. Figure 2 shows that organizational identification did not increase voice for managers with high scores in authentic leadership, but increased the tendency for voice of those low in authentic leadership. Thus, organizational identification seems to substitute for authentic 
leadership but may not further increase voice for authentic leaders.

\section{$<$ Insert Figure 2 Here $>$}

In Hypotheses 3a, we expected that leader team prototypicality moderates the effect of organizational identification on voice. Table 2 shows that prototypicality negatively moderates the relation between organizational identification and voice, $\beta=-.20, t(1,105)=-1.96, p<$ .05. It is to be noted that the bootstrapped 95\% CI interval for this coefficient did include zero, but not with the $90 \% \mathrm{CI}^{2}$. As shown in Figure 3 and in line with Hypothesis 3a, leader team prototypicality seems to suppress the effect of organizational identification on voice. The slope gradient for low prototypicality, $\beta=.65, t(1,102)=7.33, p<.0001$, was significantly steeper than for high levels of prototypicality, $\beta=.35, t(1,102)=3.07, p<.01$.

\section{<Insert Figure 3 Here>}

To test Hypothesis 3b, we examined the three-way-interaction between authentic leadership, organizational identification, and leader team prototypicality in predicting voice. Table 3 shows regression coefficients and bootstrapped SE and 95\% CI for authentic leadership, organizational identification and prototypicality, and their respective cross-product term as predictors of voice. Entering the control variables in Step 1 explained $52.1 \%$ of total variance, $\Delta R^{2}=.52, F(5,105)=22.81, p<.0001$ with neglect emerging as the only significant unique predictor, $\beta=-.63, t(5,105)=-5.81, p<.001$. At Step 2, entering authentic leadership, organizational identification, and prototypicality explained an additional $9 \%$ variance, $\Delta R^{2}=$ $.09, F(3,102)=7.88, p<.0001$. Authentic leadership emerged as a significant predictor of voice, $\beta=.39, t(8,102)=4.11, p<.0001$, whereas organizational identification and prototypicality did not, $\beta=.08, t(8,102)=.91, p=.36$ and $\beta=-.04, t(8,102)=-.69, p=.49$, respectively. At Step 3, we entered the three two-way interaction terms, but the increment in

${ }^{2}$ For interaction effects, the conventional level of $p$ is 0.10 to protect the test from the probability of committing a Type II error when moderating analyses are performed (Caplan \& Jones, 1975; Champoux \& Peters, 1987; Rodríguez, Bravo, Peiró, \& Schaufeli, 2001). 
explained variance was non-significant, $\Delta R^{2}=.01, F(3,99)=.98, p=.40$. At the final step, the three-way interaction term was entered. As can be seen in Table 3 and in line with Hypothesis $3 \mathrm{~b}$, the product-term of authentic leadership, organizational identification, and prototypicality was a significant predictor of voice, $\beta=-.18 t(12,98)=-1.96, p<.05$, accounting for an additional $1.4 \%$ of the variance, $\Delta R^{2}=.01, F(1,98)=3.82, p<.05$.

\section{<Insert Table 3 Here>}

\section{$<$ Insert Figure 4a Here>}

Figure $4 \mathrm{a}$ shows the results of the three-way interaction separated for managers high and low in authentic leadership. As can be seen on the left-hand side of Figure 4a, for managers that are high in authentic leadership, prototypicality decreases voice for those with high scores in organizational identification. This suppressor effect does not show for low prototypicality. For managers low in authentic leadership, as can be seen on the right-hand side of Figure 4a, prototypicality did not interfere with the voice increasing effect of organizational identification. Notably, although single slope gradients did not reach significance, low prototypicality seems to increase voice for managers' low in authentic leadership and high in organizational identification. Slope analyses revealed significant slope gradient differences in organizational identification between high and low levels of authentic leadership when prototypicality was high, $t(2,99)=-2.58, p<.01$.

\section{Discussion}

Results supported the hypothesized main (Hypotheses 1 and 2a) and interaction effects (Hypothesis 2b) of authentic leadership and organizational identification on voice. Note that Hypothesis $2 b$ was partially supported, as organizational identification increased voice only for inauthentic managers, but not for authentic managers. Thus, identification with the organization seems to compensate for authentic leadership but does not augment the effect of authentic leadership when it comes to predicting voice. Leaders' team prototypicality did 
moderate the relationship between organizational identification and voice supporting Hypothesis 3a. Finally, the significant three-way interaction predicting voice by the combined effects of authentic leadership, organizational identification, and team prototypicality support Hypothesis $3 b$. In line with Hypothesis $3 b$, the positive impact of organizational identification on the relationship between authentic leadership and voice diminishes for prototypical managers. This disturbing effect of a team prototypicality that contrasts with organizational identification emerged only for authentic managers.

In sum, the pattern of results supports the benefits of authentic leadership and organizational identification but leaves doubts regarding the role of team prototypicality. Based on findings that high team prototypicality increases team-oriented behavior, we expected team prototypicality to increase the salience of their role as team leaders, driving managers in the high team prototypicality condition to show less voice. This was not the case as can be seen in Figures $3 \mathrm{a}$ and $\mathrm{b}$. Even more surprising, given the state of existing research on team prototypicality (van Knippenberg, 2011), high team prototypicality seems to increase voice for inauthentic managers. This finding contradicts what we expected based on the literature on team prototypicality. However, it might be explained by the "license to fail" effect. Giessner and van Knippenberg (2008; see also Ullrich, Christ, \& van Dick, 2009) have shown that prototypical leaders are given certain leeway by their followers, such as higher tolerance to violate procedural fairness or failure to reach goals. Our findings might indicate that managers might have assumed that they have this kind of credit from their followers when they are prototypical. Researchers that linked the role of prototypicality to cases of political leaders (Haslam et al., 2011; Reicher, Haslam, \& Hopkins, 2005) argued that some leaders use prototypicality to leverage their status within their groups. Thus, the somewhat surprising finding that team prototypicality increased voice for identified yet inauthentic managers could be interpreted in a way that prototypical leaders who identify with their organization may feel 
that they have enough social capital in their team to voice concerns. We will examine this interpretation in Study 2.

\section{Study 2}

The possibility that team prototypicality could not only interfere with voice but also, at least for some managers, increase voice, induces a new facet to the role of team prototypicality in manager behavior and its possible combined effects with other predictors of voice. To reconfirm our findings and to investigate further the role of team prototypicality in predicting voice and its combined effects with authentic leadership and organizational identification, we conducted a second study. In Study 2, we use the same procedure as in Study 1 but, based on Study 1's findings, we adjust our hypotheses in the following way. Given that our prior results show that authentic leadership and organizational identification have an effect on voice, we expect the similar effects in Study 2. As Hypothesis $2 b$ was confirmed for inauthentic managers but not for authentic managers, we specify:

Hypothesis 1: Authentic leadership is positively related to managerial voice.

Hypothesis 2a: Organizational identification is positively related to managerial voice.

Hypothesis 2b: Organizational identification moderates the relationship between authentic leadership and voice, so that this relation will be stronger for inauthentic managers.

Regarding Hypotheses $3 \mathrm{a}$ and $3 \mathrm{~b}$, we adhered to our expectation concerning the combined effects of authentic leadership, organizational identification, and team prototypicality on voice. Our rationale is that these hypotheses reflect existing state of the art research and evidence and might not be rejected based on the findings of just one study. However, Study 1 results showed that for those managers who are low in authentic leadership but who highly identify with their organization, team prototypicality increased voice. When 
discussing these results, we argued that this leveraging effect might be caused by managers relying on the specific leeway that prototypical leaders have. So far, this "license to fail" (Giessner \& van Knippenberg, 2008) has only been shown in research that examined followers' perceptions of leaders who were either prototypical or not. This research revealed that prototypical leaders are given higher tolerance to violate procedural fairness or fail to reach goals (Giessner \& van Knippenberg, 2008; Ullrich et al., 2009). We assume that managers are (implicitly or explicitly) aware of this leeway and use it to implement their agenda. In our example, only highly identified managers should use this leeway, because it allows them to benefit their organization. For unidentified managers, there is no motivation at all to take the risk to act/speak against their group and thus risk losing group support. Thus, we expect:

Hypothesis 3a: Leader's team prototypicality will moderate the relation between organizational identification and voice so that this relation weakens as team prototypicality increases.

Hypothesis 3b: Leader's team prototypicality moderates the relationship between authentic leadership, organizational identification, and voice. For authentic managers, team prototypicality will diminish the effect that organizational identification has on voice.

Hypothesis 3c: Leader's team prototypicality moderates the relation between authentic leadership, organizational identification, and voice. For highly identified yet inauthentic managers, team prototypicality will increase the positive effect that organizational identification has on voice.

A possible explanation for the mixed results for team prototypicality might be rooted 
in the cultural background of our sample. Prior research has shown that leadership styles differ across cultures (Hofstede, 1980; House et al., 2004) and so may managers' weighing of their team vs. organizational orientation. Particularly German managers, which formed the majority of Study 1's sample, have been described as low in team orientation, but with high regard for their organizations (Brodbeck, Frese, \& Javidan, 2002). To examine this possible cultural explanation of our findings, in Study 2, we use a U. S. sample.

\section{Method}

\section{Participants and design}

Study 2 sample consisted of 325 participants (36.9\% female) with a mean age of 33.72 $(S D=11.25)$, being $80 \%$ white/Caucasian, $7.4 \%$ Afro-American, 5.2\% Hispanic/Latino, $6.8 \%$ Asian-American, and $0.6 \%$ Native-American. At the time of the survey, $82.5 \%$ were employed, $5.5 \%$ were unemployed, $4.9 \%$ were part-time students, and $3.7 \%$ were full-time students; $71.1 \%$ our sample declared having a permanent work contract, $26.5 \%$ having a limited contract and $2.2 \%$ did not indicate their contract type. Forty-seven percent of our sample held a managerial position, ranging from 1 to 300 employees $(M=5.71, S D=19.11)$ at their charge. While $45.3 \%$ did not hold managerial positions, $30.8 \%$ of our participants were project team leaders, $16.9 \%$ were department managers, $5.8 \%$ were division managers and $1.2 \%$ were executive board members. A wide array of sectors was represented in our sample, with retail (14.5\%), information technologies (12.6\%) and healthcare $(9.2 \%)$ being the most representative sectors.

\section{Measures}

We used the same measures as in Study 1. Cronbach's alpha's were within the accepted range for authentic leadership $(\alpha=.89)$, organizational identification $(\alpha=.85)$, the EVLN scales exit $(\alpha=.94)$, voice $(\alpha=.77)$, loyalty $(\alpha=.74)$, and neglect $(\alpha=.78)$, and leader's team prototypicality $(\alpha=95)$. 
In addition to the control variables used in Study 1, we controlled for participants' managerial role using a dummy coded variable $(0=$ yes $/ 1=n o)$, as not all of our participants held a managerial position. Further, we controlled for participants' number of direct reports (managerial span of control), because we expect that managers of smaller teams establish closer leader-member relationships (Schyns, Maslyn, \& Weibler, 2010), and in consequence be more reluctant to raise voice if the latter conflicts with their team's interest.

\section{Results}

\section{Preliminary analyses and manipulation check}

We first examined whether the assumptions of linear models were met. We used the same criterion as in Study 1 to identify outliers and removed three participants based on their score in the voice variable ${ }^{3}$ Independent samples $t$-test show that our manipulation had the intended effect, as participants in the high team prototypicality condition reported significantly higher scores of team prototypicality, $t(323)=-13.32, p<.001$, than those in the low prototypicality condition, $M=5.59, S E=.06$ vs. $M=4.62, S E=.13$.

Our CFA results show that the two-factor model, that is with authentic leadership taken as higher-order construct and organizational identification $\left(\mathrm{S}-\mathrm{B} \chi^{2}=285.49 ; p<.05 ; \chi^{2} / \mathrm{DF}=\right.$ $1.97 ; \mathrm{RMSEA}=.05 ; \mathrm{NNFI}=.92 ; \mathrm{CFI}=.93)$ fits our data better that the single-factor model $\left(\mathrm{S}-\mathrm{B} \chi^{2}=755.85 ; p<.05 ; \chi^{2} / \mathrm{DF}=4.97 ; \mathrm{RMSEA}=.011 ; \mathrm{NNFI}=.66 ; \mathrm{CFI}=.70\right)$. Again, the S-B scaled corrected $\chi^{2}$ difference test, show that both the 5-factor model, $\Delta \chi^{2}(10)=429.23, p$ $<.001$, and the two-factor model, $\Delta \chi^{2}(7)=381.43, p<.001$, fitted the data better than the single factor model. Further, Hartmann test confirmed that the two-factor model fits the data better than the 5-factor model. Again, this evidences that participants did not confuse authentic leadership with organizational identification, and justifies using authentic leadership as a

${ }^{3}$ Three outliers where identified for Voice $(.92 \%)$ as dependent variable. Again, not excluding these outliers would have induced a Type II error in our regression analyses. 
composite scale.

\section{Hypotheses testing}

The upper diagonal of Table 1 shows means, $S D$, and bivariate correlations of all study variables. Again, in line with Hypotheses 1 and 2a, authentic leadership and organizational identification were positively related to voice.

Table 2 shows regression coefficients and bootstrapped 95\% Confidence Intervals (CI) for the direct and combined effects of authentic leadership and organizational identification on voice that we used to test for moderation (Hypothesis 2b). OLS regressions showed that, as expected, authentic leadership and organizational identification predicted Voice, $\beta=.34, t(3$, $320)=6.36, p<.001$ and $\beta=.12, t(3,320)=2.40, p<.05$, respectively. In line with Hypothesis $2 \mathrm{~b}$, the interaction term predicted voice, $\beta=-.13, t(3,320)=-2.39, p<.05$. Bootstrapped $95 \%$ $\mathrm{CI}$ showed that none of the significant regression coefficients included zero. Figure $2 \mathrm{~b}$ shows a similar pattern of slope graphs as shown in Figure 2a for Study 1 slopes. Thus, our results support our specified Hypothesis $2 b$ about the substitute effect of organizational identification on the link between authentic leadership and voice.

In Hypothesis 3a, we predicted that team prototypicality moderates the effect of organizational identification on voice. As can be seen in Table 2, OLS support the moderation hypothesis, $\beta=.17, t(1,322)=2.23, p<.05$. Bootstrapped $95 \% \mathrm{CI}$ interval for the crossproduct coefficient did include zero, but not at the $90 \%$ CI level. Again, we advise caution when interpreting this result. A comparison of the slopes for the interaction effect of prototypicality and identification on voice for Studies 1 and 2 (Figures 3a and 3b) reveals that for both cases, an increase in organizational identification leads to an increase in voice. In Study 2 , the slope for high prototypicality is steeper than the slope for low prototypicality, $\beta=$ $.35, t(1,319)=4.71, p<.0001$ vs. $\beta=.12, t(1,319)=1.73, p=n s$. This pattern provides additional support for the leverage effect of prototypicality on voice that we expected based on 
the findings of Study 1. Moreover, regression analyses shown in Table 2 indicate that in the $\mathrm{U}$. S. sample compared to the mainly German sample, not only prototypicality is more important, but organizational identification also seems to be a less important predictor for voice. This result further supports our interpretation that whereas a leader's team prototypicality is more important than his/her organizational identification to U. S. managers, the opposite occurs for German managers.

In Hypotheses $3 \mathrm{~b}$ and $\mathrm{c}$, we examined the role of prototypicality as a moderator on the relationships between authentic leadership, organizational identification, and voice using hierarchical regression analysis. Table 3 shows regression coefficients and bootstrapped 95\% CI for authentic leadership, organizational identification, and prototypicality, and their respective cross-product term as predictors of voice. Step 1 of the regression explained $21 \%$ of the variance in voice. Again, neglect emerged as the only (negative) predictor of voice, $\beta=-$ $.35, t(7,301)=-5.22, p<.001$. In Step 2, we entered the predictors authentic leadership, organizational identification, and prototypicality which increased explained variance by $6.4 \%$, $\Delta R^{2}=.06, F(3,298)=8.76, p<.0001$. All three predictors explained unique variance in voice: Authentic leadership, $\beta=.16, t(10,298)=4.91, p<.001$; organizational identification, $\beta=.16$, $t(10,298)=2.92, p<.001 ;$ and prototypicality, $\beta=.11, t(10,298)=2.26, p<.05$. The fact that, when controlling for authentic leadership and organizational identification, prototypicality increases voice, supports the leveraging effect of prototypicality that we expected based on Study 1 findings.

Notably, in contrast to Study 1 findings where prototypicality and voice (and exit, loyalty, and neglect, respectively) were not related, in Study 2, perceiving oneself as prototypical for one's team increased the tendency for voice even when we do not control for authentic leadership and organizational identification (as shown in Table 1). This finding supports the assumption that for US managers, the potential leverage effect of prototypicality 
is even stronger. In both samples, however, managers who perceived themselves as prototypical seem to draw upon their prototypical leeway (Giessner \& van Knippenberg, 2008) to take a risk and engage in voice.

After entering the three two-way interactions in Step 3, which did not increase explained variance significantly, $0.2 \%, \Delta R^{2}=.002, F(3,295)=.23, p=.88$, in Step 4, we included the three-way interaction including authentic leadership, organizational identification and prototypicality. In line with our expectations, including the three-way interaction increased explained variance by $1.2 \%, \Delta R^{2}=.01, F(1,294)=5.06, p<.05$. The regression coefficient for the three-way interaction term was significant with a similar effect size as in Study $1, \beta=-$ $.16, t(14,294)=-2.25, p<.05$, and with OLS 95\% CI that did not include zero. However, while null hypothesis testing indicates that the interaction term is significant, the nonparametric approach shows that bootstrapped CI include zero at $95 \%$ level, but not at the $90 \%$ level. Therefore, even though we treat the interaction term as significant, we again advise caution when interpreting this result (Cumming, 2014).

To test the specified Hypotheses $3 \mathrm{~b}$ and $3 \mathrm{c}$, we then examined whether prototypicality suppresses or leverages the positive effect of organizational identification on voice separately for managers high and low in authentic leadership. As can be seen on the left-hand side of Figure $4 \mathrm{~b}$, the horizontal slope for high prototypicality signals that for managers high in authentic leadership, high perceptions of prototypicality seem to suppress the positive effect of organizational identification on voice. This finding is in line with Hypothesis $3 \mathrm{~b}$ in which we expected that their sensitivity to self-relevant cues makes managers high in authentic leadership liable to interfering self-relevant cues. For managers high in authentic leadership but low in prototypicality, this suppression effect seems to be absent and thus higher organizational identification is related to higher voice. For inauthentic managers (see right-hand side of Figure 4b), the pattern of slopes looks similar to the Study 1 results (see right-hand side of Figure 4a). 
Again, for inauthentic managers, higher organizational identification relates to more voice when managers are prototypical for their team. This result supports Hypothesis $3 \mathrm{c}$ in which we expected that managers who are high in organizational identification use their license to fail to implement action that benefits the organization. Simple slope analysis further supports Hypotheses $3 b$ and $3 c$ as the slope gradients for organizational identification were significant for high authentic leadership and low team prototypicality, $\beta=.25, t(1,294)=2.07, p<.05$, and also for low authentic leadership and high leader team prototypicality, $\beta=.22, t(1,294)=$ $2.59, p<.01$.

\section{Discussion}

Study 2 aimed at replicating the results of Study 1 in a larger sample from a different cultural cluster (i.e., Anglo-Saxon cluster, House et al., 1999) and confirming our posthoc interpretations based on the license to fail effect (Giessner \& van Knippenberg, 2008) which we included as specified hypotheses. Our results show that the direct effects of authentic leadership and organizational identification, as well as the supplementary effect of organizational identification, generalize to the U. S. sample. In contrast to Study 1, team prototypicality played a more important role in the U. S. sample compared to the mainly German sample, as indicated by the positive direct effect of team prototypicality on voice. Our

results suggest that for prototypical U. S. managers, organizational identification and authentic leadership had almost similar effects on voice. Further, these variables also had an interactive effect. Notably, in the U. S. sample, for organizational identification to substitute entirely for authentic leadership, managers must feel highly representative of their teams.

\section{General Discussion}

Prior approaches to explain employee voice focused mainly on costs vs. safety and perceived efficacy vs. futility of voice elaborations (Morrison, 2011). The primary goal of our study was to complement these approaches by examining the influence of three self-related 
factors on prohibitive voice (i.e., voice aimed at preventing the organization from harm). Selfexpression has been shown to be a strong motivator for organizational behavior in general and ethical behavior in particular (Aquino \& Reed, 2002; Shamir, 1991). In line with our hypotheses, we found that authentic leadership and organizational identification have direct effects on voice. Our prediction regarding an interaction effect of authentic leadership and organizational identification was also supported in a way that indicates that organizational identification substitutes for the effect of low authentic leadership on managerial voice. The expected cumulative effect was not observed, as organizational identification did not increase authentic managers' tendency to engage in voice behaviors.

Our manipulation of team prototypicality, the third self-related factor we examined, leads to new insights into the role of prototypicality as a predictor of voice and managerial behavior in general. High (self-perceived) team prototypicality decreased voice but only for highly identified authentic managers while it did not influence voice in the other conditions. This pattern suggests that team prototypicality influences managerial voice through two processes: For highly identified authentic managers, high team prototypicality seems to interfere with the feeling of oneness they experience with their organization (i.e., organizational identification) leading to less voice. This interpretation is backed by the finding that team prototypicality also weakened the effect that organizational identification on managerial voice, but only in Study 1. For highly identified inauthentic managers, in contrast, team prototypicality seems to function as a strengthening factor that further increases voice. As this effect emerged in both studies, it deems appropriate to assume that managers with this status use their "prototypical leeway" (Giessner \& van Knippenberg, 2008) to take risks and implement action that benefits their organization. This effect, however, occurs only for identified managers; less identified managers seem to lack the motivation to benefit the organization and thus are not affected by self-perceived team prototypicality. 


\section{Theoretical Implications}

Our findings support our approach to complement cost-benefit thinking by considering self-related constructs as antecedents of voice. We furthermore developed theory and provided preliminary evidence how three self-related constructs may interact to produce voice. A reasonable next step is to proceed with building an integrated theory of self-related constructs as antecedents of voice. We proposed that Organismic Integration Theory (OIT), a sub-theory of Self-determination theory (Gagné \& Deci, 2005; Ryan \& Deci, 2000) could be useful to guide on this endeavor. That is why we use it as a framework to discuss the implementations of our most important findings.

The regulation mechanisms described by OIT not only offer a plausible explanation for why identified authentic managers engage in voice, but also why organizational identification increased voice for inauthentic managers. According to OIT, our self-concept collects endorsed values and goals, and an individual transforms socially sanctioned norms and expectations into different forms of behavioral regulations through a process called internalization. These regulations enable managers to express their self-relevant goals and values at work, despite situational constraints (e.g., workplace characteristics, role demands) that might restrict their expression (Ibarra, 2015; Lord \& Hall, 2005). Among the different regulation types, integrated regulation is the most autonomous and thus the regulatory style of authentic managers, as this behavioral regulation reflects and is coherent with their sense of self-concept (Gardner et al., 2005). Our results show, in line with Knoll and van Dick's (2013) findings on trait authenticity, that authentic leadership is one of the strongest predictors of managerial voice (Hypothesis 1), and relatively independent of other factors such as organizational identification.

Although most valuable, due to situational constraints at work, integrated regulation might not be possible to achieve for all managers or in every workplace (Ibarra, 2015). In such situations, identified regulation is most valuable, a form of functioning that occurs when an 
actor accepts a social norm or behavior as valuable or important (Gagné \& Deci, 2005; Ryan \& Deci, 2000). A manager who identifies with an entity (in our study, the organization) likely behaves in a way that makes this entity flourish. Although such behavior is not entirely integrated, identified action represents behavior that is based on the acceptance of external values as one's own and thus expresses important aspects of the self. Our finding that organizational identification directly affected voice (Hypothesis 2a), yet, not as strong as authentic leadership, is in line with OIT. Moreover, organizational identification increased voice only for inauthentic managers indicating that authentic leadership is essential and a lower level regulation mechanism can not increase its effect on behavior regulation. However, the lower level regulation mechanism identification can supplement (Hypothesis 2b) for low scores on the higher level mechanism 'integrated functioning' (which is somewhat similar to authentic leadership).

Results for leaders' (self-perceived) team prototypicality differed from the expectations that we derived from the current state of team prototypicality research (van Knippenberg, 2011). The positive effect of team prototypicality on voice for identified managers indicates that team prototypicality does not need to be a disadvantage, especially for managers who are interested in the benefit of the organization. Identified managers seem to use the leeway that prototypical leaders have (Giessner \& van Knippenberg, 2008) to implement actions that benefit the organization yet might have disadvantages for the team. So far, this "license to fail" was shown only in research on leader perceptions as reported by followers. Our research indicates that leaders are (at least implicitly) aware of this leeway and use it to implement their goals. However, it also shows that team prototypicality might not be all positive, as it might interfere with other self-relevant motives such as consistent self-expression that is particularly valued by authentic leaders. Becoming aware of discrepant obligations (here toward the organization and the team) might be a threat that might be particularly dangerous for leaders 
who screen events to validate their selves. Particularly authentic leaders who aim at the integration of the different aspects of their selves and that are sensitive to external cues for validating their self-concepts might become unsettled if they learn that two parts of their identity collide.

Another (unexpected) implication of our study was that the influence of team prototypicality differed between cultures. Overall, our data support our predictions across two samples, showing similar patterns for voice in both Germany and the US. However, among the differences between samples, team prototypicality positively influenced US managers' voice but did not affect German managers' voice, while for the latter, organizational identification was a stronger driver of voice. One explanation for this might be that in Germanic countries (House et al., 1999), authentic managers will speak up no matter what, but inauthentic managers will only speak up if they identify with their organizations, even though if this would mean to disappoint their teams. Our results seem aligned with previous findings, describing German managers as low in team orientation, but with high regard for institutions (Brodbeck et al., 2002). In the U. S. sample, team prototypicality had a significant effect on voice, also playing an essential role in the above-mentioned supplementary effect. When we considered team prototypicality, only prototypical authentic managers expressed voice, independent from their organizational identification. Instead, for authentic but non-prototypical managers, we found only a supplementary effect.

Finally, the joint effect of team prototypicality and organizational identification entirely substituted for low levels of authentic leadership, suggesting that a first step on the road to authentic leadership is acknowledging the power that followers grant (DeRue \& Ashford, 2010).

\section{Practical implications}

Achieving the self-knowledge necessary for an authentic leadership requires among 
other things, a consistent investment in self-development (Lord \& Hall, 2005), or in Socrates' words, "by conquering oneself; the first and greatest of all victories" (Bloom, 1991). Organizations can help managers to develop their authentic leadership by providing training focused on self-awareness and regulation. More precisely, focusing on self-awareness would include (a) the use of introspective self-reflection to understand how managers derive the meaning of the world around themselves, and (b) making such self-schemas explicit. Similarly, a focus on self-regulation would imply (a) the setting of internal standards and rules of conduct, which can be existing standards or newly formulated ones, (b) the evaluation of discrepancies between these standards and actual or potential outcomes, and (c) the identification of intended actions for resolving these discrepancies (Gardner et al., 2005).

Those organizations that may not want to rely on such internal growth processes may take action to create contextual conditions that foster voice. In addition to Morrison's (2011) suggestions for promoting a safe voice culture, organizations can encourage managerial voice if they facilitate their managers' organizational identification. For example, organizations can try to make managers feel as valuable members by actually empowering them through higher autonomy and decision latitude, or by adopting top-down participative approaches to everyday operations, as it occurs in many German organizations.

With regard to using the voice-facilitating effect of prototypicality, those who are in charge of project teams' formation could install leaders who share similar work characteristics with the teams they are proposed to lead (e.g., same values, work philosophy, or a previous history of collaborating), and leaders could install procedures and context conditions that remind followers of his or her prototypicality. Note that while prototypical leaders are granted some leeway to not always act in the group's interest (which might include prohibitive voice), other research pointed at the threat of too much similarity among leaders and followers (e.g., Janis, 1982). Future research may examine the strength of the respective underlying processes 
and their dominance in particular settings.

Our work is not without limitations. Our study only explored drivers of managerial voice in two western cultures, and could not generalize across countries. Future studies might aim to replicate our work in a larger cross-cultural sample, including Eastern European, African, or Latin-American countries. Exploring how organizational identification and team prototypicality are affected by cultural values (e.g., individualism vs. collectivism) or interact with cultural dimensions to predict voice could specify our findings. However, research on the link between voice and culture is in its infancy (see Kwon \& Farndale, in press).

Our results show the relevance of self-related motives for managerial voice. A selfcongruent expression within a leadership role is a significant predictor of voice, but other motives such as identification are necessary when authentic leadership is not present. Further, the self is not only a relatively stable driver of managerial behavior but relevant to managers' response to situational cues. In line with the license to fail effect, a leader's self-perceived team prototypicality increased voice although it was to the disadvantage of the team. Our results enrich the knowledge on why managers express their views despite the difficulties arising from this kind of behavior, a topic that is also present in recent public scandals (e.g., WikiLeaks, NSA). Our results might drive future research extending the scope of theories explaining voice and silence towards an integration of self-relevant theories into an overarching motivational framework of voice. Finally, our results generalize across two central western countries and identify potential cultural specifics that might be worth examining in more detail in the future. 


\section{References}

Aiken, L., \& West, S. G. (1991). Multiple regression: Testing and interpreting interactions. Thousand Oaks, CA: Sage.

Algera, P. M., \& Lips-Wiersma, M. (2012). Radical authentic leadership: Co-creating the conditions under which all members of the organization can be authentic. The Leadership Quarterly, 23, 118-131. http://doi.org/10.1016/j.leaqua.2011.11.010

Aquino, K., \& Reed II, A. (2002). The self-importance of moral identity. Journal of Personality and Social Psychology, 83, 1423-1440. http://doi.org/10.1037/0022-3514.83.6.1423

Ashford, S. J., Sutcliffe, K. M., \& Christianson, M. K. (2009). Speaking up and speaking out: The leadership dynamics of voice in organizations. Voice and silence in organizations. In J. Greenberg \& M. S. Edwards (Eds.), Voice and silence in organizations ( $1^{\text {st }}$ Ed., pp. 175-202). Bingley, UK: Emerald Group Publishing Limited.

Ashforth, B. E., \& Mael, F. (1989). Social identity theory and the organization. Academy of Management Review, 14, 20-39. http://doi.org/10.5465/AMR.1989.4278999

Audi, R., \& Murphy, P. E. (2006). The many faces of integrity. Business Ethics Quarterly, 16, 3-21. https://doi.org/10.5840/beq20061615

Bazerman, M. H., \& Gino, F. (2012). Behavioral ethics: Toward a deeper understanding of moral judgment and dishonesty. Annual Review of Law and Social Science, 8, 85-104. http://doi.org/10.1146/annurev-lawsocsci-102811-173815

Blasi, A. (1980). Bridging moral cognition and moral action: A critical review of the literature. Psychological Bulletin, 88, 1-45. http://doi.org/10.1037/0033-2909.88.1.1

Bloom, A. (1991). The Republic of Plato (2 ${ }^{\text {nd }}$ Ed.). NewYork, NY: Basic Books.

Brodbeck, F. C., Frese, M., \& Javidan, M. (2002). Leadership made in Germany: Low on compassion, high on performance. Academy of Management Perspectives, 16, 16-29. http://doi.org/10.5465/AME.2002.6640111

Burris, E. R. (2012). The risks and rewards of speaking up: Responses to voice in organizations. 
Academy of Management Journal, 55, 851-875. https://doi.org/10.5465/amj.2010.0562

Caplan, R. D., \& Jones, K. W. (1975). Effects of work load, role ambiguity, and Type A personality on anxiety, depression, and heart rate. Journal of Applied Psychology, 60, 713-719. http://doi.org/10.1037/0021-9010.60.6.713

Chamberlin, M., Newton, D. W., \& Lepine, J. A. (2017). A meta-analysis of voice and its promotive and prohibitive forms: Identification of key associations, distinctions, and future research directions. Personnel Psychology, 70, 11-71. http://doi.org/10.1111/peps.12185

Champoux, J. E., \& Peters, W. S. (1987). Form, effect size and power in moderated regression analysis. Journal of Occupational Psychology, 60, 243-255. http://doi.org/10.1111/j.2044$\underline{8325.1987 . t b 00257 . x}$

Chan, A. Y. L., Hannah, S. T., \& Gardner, W. L. (2005). Veritable authentic leadership: Emergence, functioning, and impacts. In W. L. Gardner, B. J. Avolio, \& F. O. Walumbwa, (Eds.), Authentic leadership theory and practice: Origins, effects and development (pp. 3-41). Oxford, UK: Elsevier Science.

Claxton, G., Owen, D., \& Sadler-Smith, E. (2013). Hubris in leadership: A peril of unbridled intuition? Leadership, 11, 57-78. http://doi.org/10.1177/1742715013511482

Crane, M. F., \& Platow, M. J. (2010). Deviance as adherence to injunctive group norms: The overlooked role of social identification in deviance. British Journal of Social Psychology, 49, $827-847$.

Crossan, M. M., Byrne, A., Seijts, G. H., Reno, M., Monzani, L., \& Gandz, J. (2017). Toward a framework of leader character in organizations. Journal of Management Studies, 54, 9861018. https://doi.org/10.1111/joms.12254

Cumming, G. (2014). The new statistics: Why and how. Psychological Science, 25, 7-29. http://doi.org/10.1177/0956797613504966

Gagné, M. \& Deci, E. L. (2005). Self-determination theory and work motivation. Journal of Organizational Behavior, 26, 331-362. http://doi.org/10.1002/job.322

DeRue, D. S., \& Ashford, S. J. (2010). Who will lead and who will follow? A social process of leadership identity construction in organizations. Academy of Management Review, 35, 627- 
647. http://doi.org/10.5465/amr.35.4.zok627

Detert, J. R., \& Burris, E. R. (2007). Leadership Behavior and Employee Voice: Is the Door Really Open? Academy of Management Journal, 50, 869-884. http://doi.org/10.5465/AMJ.2007.26279183

Detert, J. R., \& Edmondson, A. C. (2011). Implicit voice theories: Taken-for-granted rules of selfcensorship at work. Academy of Management Journal, 54, 461-488. http://doi.org/10.5465/AMJ.2011.61967925

Diddams, M., \& Chang, G. C. (2012). Only human: Exploring the nature of weakness in authentic leadership. The Leadership Quarterly, 23, 593-603. http://doi.org/10.1016/j.leaqua.2011.12.010

Eriksen, M. (2009). Authentic leadership: Practical reflexivity, self-awareness, and self-authorship. Journal of Management Education, 33, 747-771. https://doi.org/10.1177/1052562909339307

Fast, N. J., Burris, E. R., \& Bartel, C. A. (2014). Managing to stay in the dark: Managerial selfefficacy, ego-defensiveness, and the aversion to employee voice. Academy of Management Journal, 57, 1013-1034. https://doi.org/10.5465/amj.2012.0393

Gardner, W. L., Avolio, B. J., Luthans, F., May, D. R., \& Walumbwa, F. (2005). "Can you see the real me?" A self-based model of authentic leader and follower development. The Leadership Quarterly, 16, 343-372. http://doi.org/10.1016/j.leaqua.2005.03.003

Gardner, W. L., Cogliser, C. C., Davis, K. M., \& Dickens, M. P. (2011). Authentic leadership: A review of the literature and research agenda. The Leadership Quarterly, 22, 1120-1145. http://doi.org/10.1016/j.leaqua.2011.09.007

Giessner, S. R., \& van Knippenberg, D. (2008). "License to fail”: Goal definition, leader group prototypicality, and perceptions of leadership effectiveness after leader failure. Organizational Behavior and Human Decision Processes, 105, 14-35. http://doi.org/10.1016/j.obhdp.2007.04.002

Giessner, S. R., van Knippenberg, D., van Ginkel, W., \& Sleebos, E. (2013). Team-oriented leadership: the interactive effects of leader group prototypicality, accountability, and team identification. Journal of Applied Psychology, 98, 658-667. http://doi.org/10.1037/a0032445 
Graham, J. W. (1986). Principled organizational dissent: A theoretical essay. Research in Organizational Behavior, 8, 1-52.

Hagedoorn, M., van Yperen, N. W., van De Vliert, E., \& Buunk, B. P. (1999). Employees ' reactions to problematic events: A circumplex structure of five categories of responses, and the role of job satisfaction. Journal of Organizational Behavior, 20, 309-321. http://doi.org/10.1002/(SICI)1099-1379(199905)20:3<309::AID-JOB895>3.0.CO;2-P

Haslam, S. A., Reicher, S. D., \& Platow, M. J. (2011). The new psychology of leadership: Identity, influence, and power. London \& New York: Psychology Press.

Hernández, M., Eberly, M. B., Avolio, B. J., \& Johnson, M. D. (2011). The loci and mechanisms of leadership: Exploring a more comprehensive view of leadership theory. The Leadership Quarterly, 22, 1165-1185. http://doi.org/10.1016/j.leaqua.2011.09.009

Hofstede, G. (1980). Motivation, Leadership, and Organization: Do American Theories Apply Abroad. Organizational Dynamics, 9(1), 42-63. https://doi.org/10.1016/0090-2616(80)90013-3 Hollander, E. P., \& Julian, J. W. (1969). Contemporary trends in the analysis of leadership processes. Psychological Bulletin, 71, 387-397. http://doi.org/10.1037/h0027347

House, R. J., Hanges, P., Ruiz-Quintanilla, S. A., Dorfman, P. W., Javidan, M., Dickson, M., \& Gupta, V. (1999). Cultural influences on leadership and organizations: Project GLOBE. In W. H. Mobbley, Advances in Global Leadership (Vol. 1, pp. 171-233). Boston, MA: Emerald Group Publishing Limited.

Hsiung, H.-H. (2012). Authentic Leadership and Employee Voice Behavior: A Multi-Level Psychological Process. Journal of Business Ethics, 107(3), 349-361. https://doi.org/10.1007/s10551-011-1043-2

Ibarra, H. (2015). The authenticity paradox. Harvard Business Review, 93, 53-59.

Janis, I. (1982). Victims of Groupthink: A Psychological Study of Foreign Policy Decisions and Fiascos. Boston: Houghton - Mifflin.

Joosten, A., van Dijke, M.,van Hiel, A., \& De Cremer, D. (2014). Being "in control” may make you lose control: The role of self-regulation in unethical leadership behavior. Journal of Business Ethics, 121, 1-14. http://doi.org/10.1007/s10551-013-1686-2 
Kennedy, J. A., \& Anderson, C. (2017). Hierarchical rank and principled dissent: How holding higher rank suppresses objection to unethical practices. Organizational Behavior and Human Decision Processes, 139, 30-49. https://doi.org/10.1016/j.obhdp.2017.01.002

Kernis, M. H. (2003). Toward a conceptualization of optimal self-esteem. Psychological Inquiry, 14, 1-26. http://doi.org/10.1207/S15327965PLI1401_01

Knoll, M., Lord, R. G., Petersen, L.-E., \& Weigelt, O. (2016). Examining the moral grey zone: The role of moral disengagement, authenticity, and situational strength in predicting unethical managerial behaviour. Journal of Applied Social Psychology, 46, 65-78.

Knoll, M., Meyer, B., Kroemer, N. B., \& Schröder-Abé, M. (2015). It takes two to be yourself. An integrated model of authenticity, its measurement, and its relationship to work-related variables. Journal of Individual Differences, 36, 38-53. http://doi.org/10.1027/1614$\underline{0001 / a 000153}$

Knoll, M., \& van Dick, R. (2013). Authenticity, employee silence, prohibitive voice, and the moderating effect of organizational identification. The Journal of Positive Psychology, 8, 346-360. http://doi.org/10.1080/17439760.2013.804113

Kreiner, G. E., \& Ashforth, B. E. (2004). Evidence toward an expanded model of organizational identification. Journal of Organizational Behavior, 25, 1-27. http://doi.org/10.1002/job.234

Kwon, B. \& Farndale, E. (in press). Employee voice viewed through a cross-cultural lens. Human Resource Management Review. https://doi.org/10.1016/j.hrmr.2018.06.002

Lee, E.-S., Park, T. Y., \& Koo, B. (2015). Identifying organizational identification as a basis for attitudes and behaviors: A meta-analytic review. Psychological Bulletin, 141, 1049-1080. http://doi.org/10.1037/bul0000012

Leroy, H., Palanski, M. E., \& Simons, T. (2012). Authentic leadership and behavioral integrity as drivers of follower commitment and performance. Journal of Business Ethics, 107, 255-264. http://doi.org/10.1007/s10551-011-1036-1

Liang, J., Farh, C. I. C., \& Farh, J.-L. (2012). Psychological antecedents of promotive and prohibitive voice: A two-wave examination. Academy of Management Journal, 55, 71-92. http://doi.org/10.5465/amj.2010.0176 
Lord, R. G., \& Hall, R. J. (2005). Identity, deep structure and the development of leadership skills. The Leadership Quarterly, 16, 591-615. https://doi.org/10.1016/j.leaqua.2005.06.003

May, D. R., Chan, A. Y. L., Hodges, T. D., \& Avolio, B. J. (2003). Developing the moral component of authentic leadership. Organizational Dynamics, 32, 247-260. http://doi.org/10.1016/S0090-2616(03)00032-9

Mintzberg, H. (1993). Structure in fives: Designing effective organizations (p. 312). Englewood Cliffs, NJ: Prentice-Hall, Inc.

Monzani, L., Braun, S., \& van Dick, R. (2016). It takes two to tango: The interactive effect of authentic leadership and organizational identification on employee silence intentions. German Journal of Human Resource Management, 30, 246-266. https://doi.org/10.1177/2397002216649896

Monzani, L., Ripoll, P., \& Peiró, J. M. (2014). Followers ' agreeableness and extraversion and their loyalty towards authentic leadership. Psicothema, 26, 69-75. https://doi.org/10.7334/psicothema2013.67

Moore, C., \& Gino, F. (2013). Ethically adrift: How others pull our moral compass from true North, and how we can fix it. Research in Organizational Behavior, 33, 53-77. http://doi.org/10.1016/j.riob.2013.08.001

Morrison, E. W. (2011). Employee voice behavior: Integration and directions for future research. Academy of Management Annals, 5, 373-412. http://doi.org/10.5465/19416520.2011.574506

Morrison, E. W., \& Milliken, F. J. (2000). Organizational silence: A barrier to change and development in a pluralistic world. Academy of Management Review, 25, 706-725. https://doi.org/10.5465/amr.2000.3707697

Moschandreas, M. (1997). The role of opportunism in transaction cost economics. Journal of Economic Issues, 31, 39-58. https://doi.org/10.1080/00213624.1997.11505890

Murtha, B. R., Challagalla, G., \& Kohli, A. K. (2011). The threat from within: Account managers' concern about opportunism by their own team members. Management Science, 57, iv 1719. http://doi.org/10.1287/mnsc.1100.1298

Osborne, J. W., \& Overbay, A. (2004). The power of outliers (and why researchers should always 
check for them). Practical Assessment, Research \& Evaluation, 9. Retrieved from http://pareonline.net/getvn.asp?v=9\&n=6

Packer, D. J. (2008). Identifying systematic disobedience in Milgram's Obedience experiments: A meta-analytic review. Perspectives on Psychological Science, 3, 301-304. http://doi.org/10.1111/j.1745-6924.2008.00080.x

Palanski, M. E., \& Yammarino, F. J. (2009). Integrity and leadership: A multi-level conceptual framework. The Leadership Quarterly, 20, 405-420. http://doi.org/10.1016/j.leaqua.2009.03.008

Reicher, S., Haslam, S. A., \& Hopkins, N. (2005). Social identity and the dynamics of leadership: Leaders and followers as collaborative agents in the transformation of social reality. The Leadership Quarterly, 16, 547-568. https://doi.org/10.1016/j.leaqua.2005.06.007

Rodríguez, I., Bravo, M. J., Peiró, J. M., \& Schaufeli, W. (2001). The Demands-Control-Support Model, locus of control and job dissatisfaction: A longitudinal study. Work \& Stress, 15, 97114. http://doi.org/10.1080/02678370110066968

Ryan, R. M., \& Deci, E. L. (2000). Intrinsic and extrinsic motivations: Classic definitions and new directions. Contemporary Educational Psychology, 25, 54-67. http://doi.org/10.1006/ceps.1999.1020

Ryan, R. M., \& Deci, E. L. (2002). An overview of self-determination theory. In E. L. Deci \& R. M. Ryan (Eds.), Handbook of self-determination research (pp. 3-33). Rochester, NY: University of Rochester Press.

Schyns, B., Maslyn, J. M., \& Weibler, J. (2010). Understanding the relationship between span of control and subordinate consensus in leader-member exchange. European Journal of Work and Organizational Psychology, 19, 388-406. http://doi.org/10.1080/13594320903146485

Shamir, B. (1991). Meaning, self, and motivation in organizations. Organization Studies, 12, 405424. http://doi.org/10.1177/017084069101200304

Shamir, B., \& Eilam, G. (2005). "What's your story?" A life-stories approach to authentic leadership development. The Leadership Quarterly, 16, 395-417.

http://doi.org/10.1016/j.leaqua.2005.03.005 
Stryker, S. (1980). Symbolic interactionism: A social structural version. Menlo Park, CA:

Benjamin/Cummings Publishing Company.

Sturm, R. E., \& Monzani, L. (2017). Leadership and power. In J. Antonakis \& D. V. Day (Eds.), The nature of leadership. New York, NY: Sage Publications.

Tangirala, S., \& Ramanujam, R. (2008). Employee silence on critical work issues: The cross-level effects of procedural justice climate. Personnel Psychology, 61, 37-68. http://doi.org/10.1111/j.1744-6570.2008.00105.x

Treviño, L. K., Weaver, G. R., \& Reynolds, S. J. (2006). Behavioral Ethics in Organizations: A Review. Journal of Management, 32(6), 951-990. https://doi.org/10.1177/0149206306294258

Ullrich, J., Christ, O., \& van Dick, R. (2009). Substitutes for procedural fairness: Prototypical leaders are endorsed whether they are fair or not. Journal of Applied Psychology, 94, 235-44. http://doi.org/10.1037/a0012936

van Dick, R., Grojean, M. W., Christ, O., \& Wieseke, J. (2006). Identity and the extra mile: Relationships between organizational identification and organizational citizenship behaviour. British Journal of Management, 17, 283-301. http://doi.org/10.1111/j.1467$\underline{8551.2006 .00520 . x}$

van Dick, R., \& Kerschreiter, R. (2016). The social identity approach to effective leadership: An overview and some ideas on cross-cultural generalizability. Frontiers in Business Research in China, 10, 363-384.

van Dick, R., \& Schuh, S. C. (2010). My boss' group is my group: Experimental evidence for the leader-follower identity transfer. Leadership \& Organization Development Journal, 31, 551563. http://doi.org/10.1108/01437731011070032

van Dick, R., Lemoine, J. E., Steffens, N. K., Kerschreiter, R., Akfirat, S. A., Avanzi, L., ... Haslam, S. A. (2018). Identity leadership going global: Validation of the Identity Leadership Inventory across 20 countries. Journal of Occupational and Organizational Psychology, 91, 697-728. https://doi.org/10.1111/joop.12223

van Dyne, L., Ang, S., \& Botero, I. C. (2003). Conceptualizing employee silence and employee voice as multidimensional constructs. Journal of Management Studies, 40, 1359-1392. 
http://doi.org/10.1111/1467-6486.00384

van Dyne, L., Cummings, L. L., \& Parks, J. M. (1995). Extra-role behaviors-In pursuit of construct and definitional clarity (a bridge over muddied waters). Research in Organizational Behavior, $17,215-285$.

van Knippenberg, D. (2003). Intergroup relations in organizations. In M. A. West, D. Tjosvold, \& K. G. Smith (Eds.), International handbook of organizational teamwork and cooperative working (pp. 381-400). Chichester, UK: Wiley.

van Knippenberg, D. (2011). Embodying who we are: Leader group prototypicality and leadership effectiveness. The Leadership Quarterly, 22, 1078-1091. http://doi.org/10.1016/j.leaqua.2011.09.004

van Knippenberg, D., \& Hogg, M. (2003). A social identity model of leadership effectiveness in organizations. In R. M. Kramer \& B. M. Staw (Eds.), Research in organizational behavior (pp. 245-297). Amsterdam, The Netherlands: Elsevier.

van Vugt, M., Hogan, R., \& Kaiser, R. B. (2008). Leadership, followership, and evolution: Some lessons from the past. American Psychologist, 63, 182-196. http://doi.org/10.1037/0003$\underline{066 X .63 .3 .182}$

Walumbwa, F. O., Avolio, B. J., Gardner, W. L., Wernsing, T. S., \& Peterson, S. J. (2008). Authentic leadership: Development and validation of a theory-based measure. Journal of Management, 34, 89-126. http://doi.org/10.1177/0149206307308913 
Table 1.

Means, Standard Deviations and Pearson's Bivariate Correlations

\begin{tabular}{|c|c|c|c|c|c|c|c|c|c|c|c|c|c|c|c|c|}
\hline & & $M$ & $S D$ & 1 & 2 & 3 & 4 & 5 & 6 & 7 & 8 & 9 & 10 & 11 & $M$ & $S D$ \\
\hline 1. & $\mathrm{AL}$ & 3.87 & .51 & - & $.17 * *$ & -.03 & -.01 & $.15^{* *}$ & $-.17 * *$ & $.12^{*}$ & $-.18 * *$ & $.31 * *$ & $-.16 * *$ & $-.28 * *$ & 3.98 & .54 \\
\hline 2. & OID & 4.06 & .86 & $.61^{* *}$ & - & .02 & -.05 & .01 & -.02 & .09 & $-.34 * *$ & $.24 * *$ & -.09 & $-.26^{* *}$ & 3.74 & .85 \\
\hline 3. & LPT & .49 & .50 & .07 & .03 & - & .003 & -.03 & -.01 & .07 & -.08 & .06 & -.02 & .02 & .51 & .50 \\
\hline 4. & National Cluster & .32 & .62 & -.04 & -.08 & -.02 & - & .08 & -.05 & .03 & -.03 & .02 & .06 & .03 & .96 & .20 \\
\hline 5. & Contract Type & .91 & .29 & .03 & $.28^{*}$ & -.07 & .11 & - & -.09 & .05 & -.17 & .01 & -.10 & -.12 & 1.69 & .51 \\
\hline 6. & Position & - & - & - & - & - & - & - & - & $-.26 * *$ & $.12 *$ & -.06 & .02 & $.11^{*}$ & .53 & .50 \\
\hline 7. & Span of control & 31.95 & 51.35 & $.21^{*}$ & $.22 *$ & -.02 & -.08 & .07 & - & - & $-.01 * *$ & $.11^{* *}$ & -.07 & -.09 & 5.71 & 18.23 \\
\hline & Exit & 1.61 & .79 & $-.48 * *$ & $-.48 * *$ & .07 & $.20^{*}$ & -.14 & - & $-.23 *$ & - & $-.14 *$ & $.20 * *$ & $.48^{* *}$ & 2.36 & 1.14 \\
\hline & Voice & 3.98 & .76 & $.66^{* *}$ & $.53^{* *}$ & -.01 & -.01 & .16 & - & .09 & $-.49 * *$ & - & $-.36 * *$ & $-.45^{* *}$ & 4.00 & .81 \\
\hline & Loyalty & 1.91 & .79 & $-.49 * *$ & $-.43 * *$ & -.01 & .05 & -.09 & - & -.11 & $.44 * *$ & $-.44 * *$ & - & $.64 * *$ & 2.57 & .91 \\
\hline & Neglect & 1.57 & .80 & $-.69 * *$ & $-.59 * *$ & .04 & .10 & -.13 & - & -.18 & $.67 * *$ & $-.69 * *$ & $.66^{* *}$ & - & 2.13 & .89 \\
\hline
\end{tabular}

Note. Statistics for Study $1(n=111)$ are shown below the diagonal and statistics for Study $2(\mathrm{n}=325)$ are shown above the diagonal. AL $=$ Authentic Leadership; OID = Org. Identification; LTP = Team Prototypicality.

$* p<.05 . * * p<.01$. 
Table 2.

Hierarchical Regression Coefficients and Bootstrapped 95\% CI for Direct and Interactive Effects of Authentic Leadership, Organizational Identification and Self-Perceived Team Prototypicality on Voice.

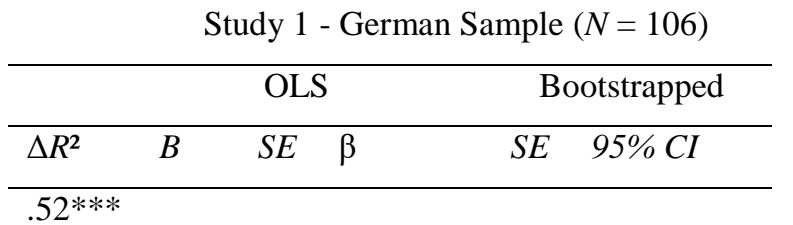

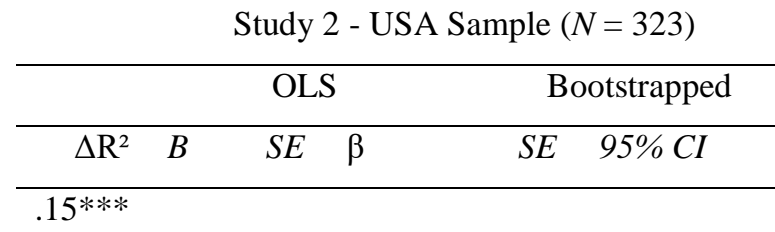

\begin{tabular}{|c|c|c|c|c|c|c|c|c|c|c|c|c|}
\hline OID & & .21 & .08 & $.22 *$ & .09 & {$[.04, .40]$} & & .09 & .05 & $.10 \dagger$ & .05 & {$[.02, .22]$} \\
\hline $\mathrm{AL}$ & & .81 & .12 & $.56 * * *$ & .14 & {$[.51,1.05]$} & & .52 & .07 & $.37 * * *$ & .07 & {$[.33, .62]$} \\
\hline \multirow{4}{*}{ AL x OID } & $.04 * *$ & & & & & & $.01 *$ & & & & & \\
\hline & & -.24 & .08 & $-.23 * *$ & .08 & {$[-.42,-.10]$} & & -.21 & .09 & $-.13^{*}$ & .09 & {$[-.38,-.04]$} \\
\hline & & \multicolumn{3}{|c|}{$\mathrm{R}^{2}=.56$} & \multicolumn{2}{|c|}{$f^{2}=1.27$} & & \multicolumn{3}{|c|}{$R^{2}=.17$} & \multicolumn{2}{|c|}{$f^{2}=.20$} \\
\hline & $.34 * * *$ & & & & & & $.06 * * *$ & & & & & \\
\hline OID & & .51 & .07 & $.58 * * *$ & .11 & {$[.34, .80]$} & & .23 & .05 & $.24 * * *$ & .10 & {$[-.05, .32]$} \\
\hline LTP & & -.08 & .11 & -.06 & .12 & {$[-.28, .20]$} & & .09 & .09 & .06 & .09 & {$[-.08, .26]$} \\
\hline \multirow{3}{*}{ LTP x OID } & $.02 *$ & & & & & & $.01 *$ & & & & & \\
\hline & & -.28 & .14 & $-.20 *$ & .19 & {$[-.64, .13]$} & & .22 & .10 & $.17 *$ & .13 & {$[-.04, .49]$} \\
\hline & & & $R^{2}=$ & & & $=.51$ & & \multicolumn{3}{|c|}{$R^{2}=.08$} & \multicolumn{2}{|c|}{$f^{2}=.08$} \\
\hline
\end{tabular}

Note: $\mathrm{AL}=$ Authentic leadership, OID = Organizational Identification; LTP = Self-perceived team Prototypicality; $\uparrow p .<.10, * p .<.05 ; * * p .<.01 ; * * * p .<$ $.001 ; 95 \%$ confidence intervals based on 5000 bootstrapped samples. 
Table 3.

Hierarchical Regression for Authentic Leadership, Organizational Identification and Self-Perceived Team Prototypicality over Voice.

\begin{tabular}{|c|c|c|c|c|c|c|c|c|c|c|c|c|}
\hline & \multicolumn{6}{|c|}{ Study $1(N=111)$} & \multicolumn{6}{|c|}{ Study $2(N=323)$} \\
\hline & \multicolumn{4}{|c|}{ Ordinary least squares (OLS) } & \multicolumn{2}{|c|}{ Bootstrapped } & \multicolumn{4}{|c|}{ Ordinary least squares (OLS) } & \multicolumn{2}{|c|}{ Bootstrapped } \\
\hline & $\Delta R^{2}$ & $B$ & $S E$ & $\beta$ & $S E$ & $95 \% \mathrm{CI}$ & $\Delta R^{2}$ & $B$ & $S E$ & $\beta$ & $S E$ & $95 \% \mathrm{CI}$ \\
\hline Step 1 & $.52 * * *$ & & & & & & $.21 * * *$ & & & & & \\
\hline Position $^{1}$ & & - & - & - & - & - & & -.002 & .08 & -.02 & .09 & {$[-.16, .19]$} \\
\hline Managerial Span of control & & - & - & - & - & - & & .003 & 002 & .06 & .005 & {$[.00, .02]$} \\
\hline Contract Type ${ }^{2}$ & & .20 & .19 & .07 & .23 & {$[-.24, .66]$} & & -.04 & .08 & -.03 & .07 & {$[-.18, .10]$} \\
\hline National Cluster & & .07 & .09 & .06 & .13 & {$[-.21, .30]$} & & .10 & .02 & .05 & .16 & {$[-.21, .42]$} \\
\hline Exit & & -.01 & .09 & -.01 & .08 & {$[-.16, .17]$} & & .05 & .04 & .07 & .04 & {$[-.03, .13]$} \\
\hline Loyalty & & -.09 & .09 & -.10 & .10 & {$[-.34, .08]$} & & -.10 & .06 & -.12 & .06 & {$[-.23, .02]$} \\
\hline Neglect & & -.61 & .11 & $-.63 * * *$ & .11 & {$[-.81,-.36]$} & & -.35 & .07 & $-.40 * * *$ & .07 & {$[-.49,-.20]$} \\
\hline Step 2 & $.09 * * *$ & & & & & & $.06 * * *$ & & & & & \\
\hline $\mathrm{AL}$ & & .56 & .14 & $.39 * * *$ & .20 & {$[.14, .88]$} & & .26 & .09 & $.16^{* *}$ & .10 & {$[.06, .44]$} \\
\hline OID & & .07 & .08 & .08 & .09 & {$[-.08, .26]$} & & .17 & .05 & $.15 * *$ & .07 & {$[.03, .29]$} \\
\hline $\mathrm{LTP}^{3}$ & & -.07 & .10 & -.04 & .09 & {$[-.25, .13]$} & & .18 & .08 & $.11 *$ & .08 & {$[.02, .33]$} \\
\hline Step 3 & $.01 * *$ & & & & & & .00 & & & & & \\
\hline AL x OID & & -.14 & .08 & $-.14 \dagger$ & .10 & {$[-.33, .02]$} & & -.06 & .10 & -.03 & .13 & {$[-.31, .20]$} \\
\hline AL x TP & & -.02 & .24 & -.01 & .30 & {$[-.61, .56]$} & & .07 & .17 & .03 & .20 & {$[-.33, .44]$} \\
\hline LTP X OID & & -.02 & .15 & -.02 & .17 & {$[-.36, .30]$} & & .03 & .11 & .02 & .13 & {$[-.21, .29]$} \\
\hline Step 4 & $.01 *$ & & & & & & $.01 *$ & & & & & \\
\hline \multirow[t]{2}{*}{ AL X TP X OID } & & -.31 & .16 & $-.18 *$ & .23 & {$[-.98, .01]$} & & -.45 & .20 & $-.16^{*}$ & .22 & {$[-.89, .05]$} \\
\hline & $R^{2}=.59$ & & & & $f^{2}=$ & 1.44 & $R^{2}=.29$ & & & & $f^{2}=$ & \\
\hline
\end{tabular}

Note. $\mathrm{AL}=$ Authentic leadership, $\mathrm{OID}=$ Organizational Identification, $\mathrm{LTP}=$ Self-perceived Team prototypicality

${ }^{1}$ Employee $=1 ;{ }^{2}$ Temporary $=\mathrm{x}$, Permanent $=\mathrm{y} ;{ }^{3}$ Prototypical $=1$.

$\dagger p<.10 . * p<.05 . * * p<.01 . * * * p .<.001 .95 \%$ confidence intervals based on 5,000 bootstrapped subsample. 


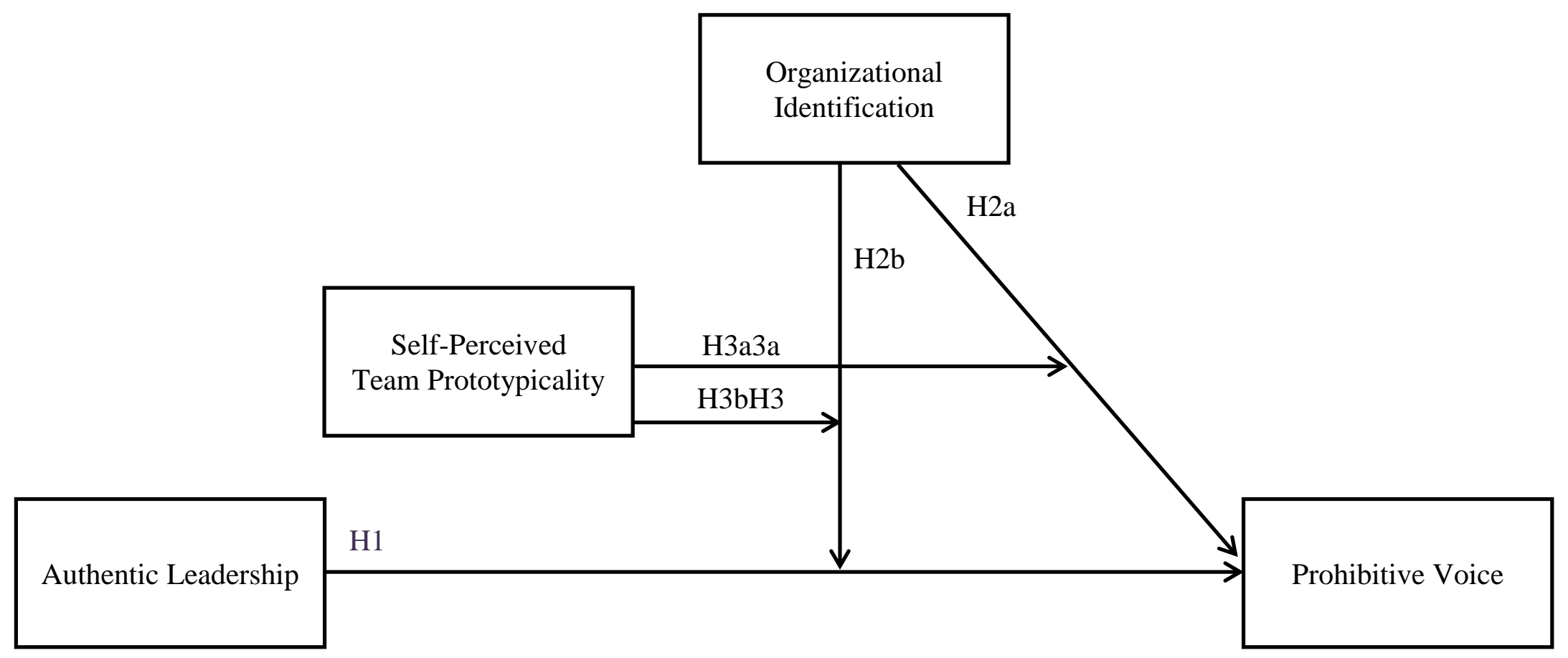

Figure 1. Model and Hypotheses 


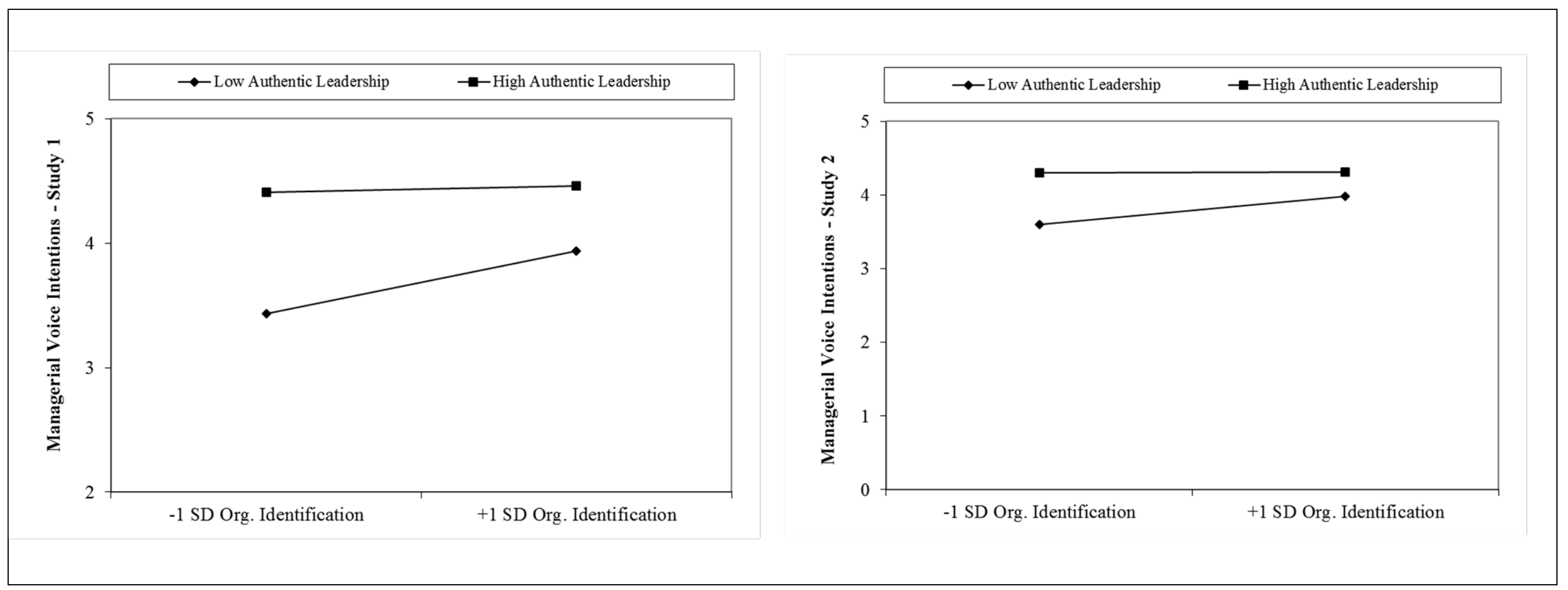

Figure 2. Interactive Effects of Authentic Leadership and Organizational Identification on Prohibitive Voice. 


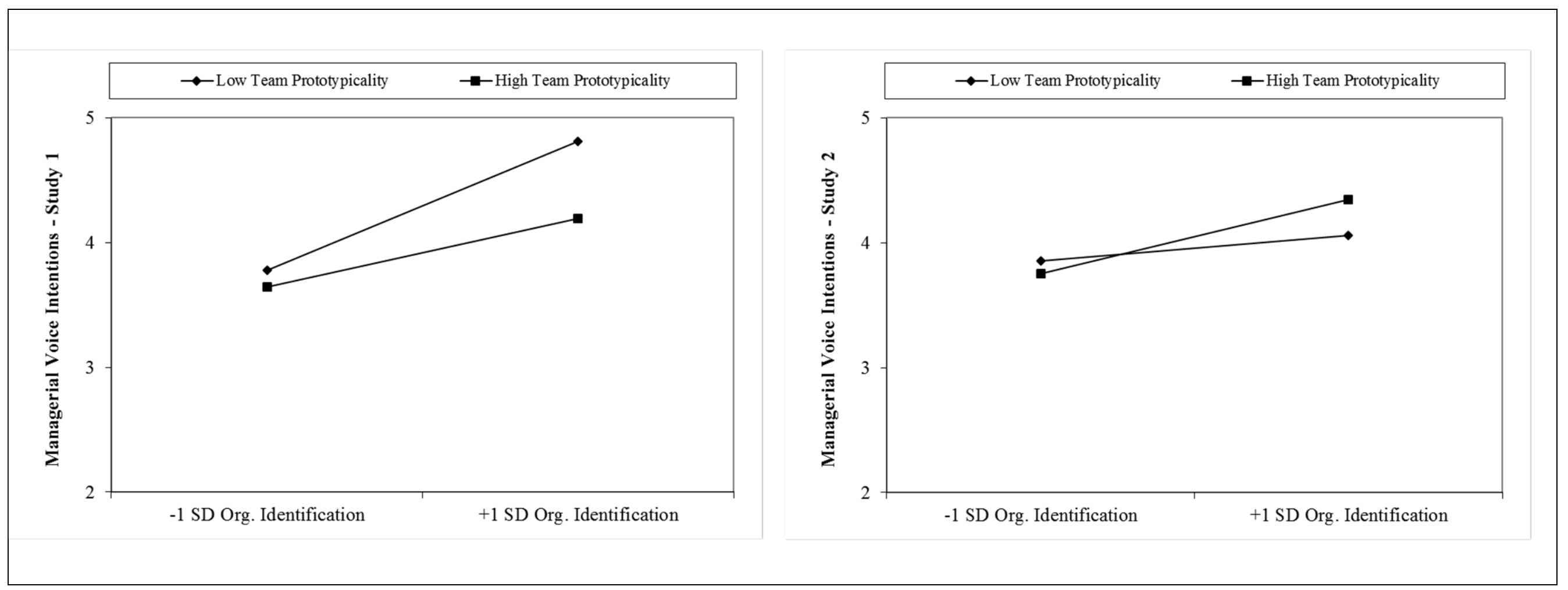

Figure 3. Interactive Effects of Organizational Identification and Team Prototypicality on Prohibitive Voice 


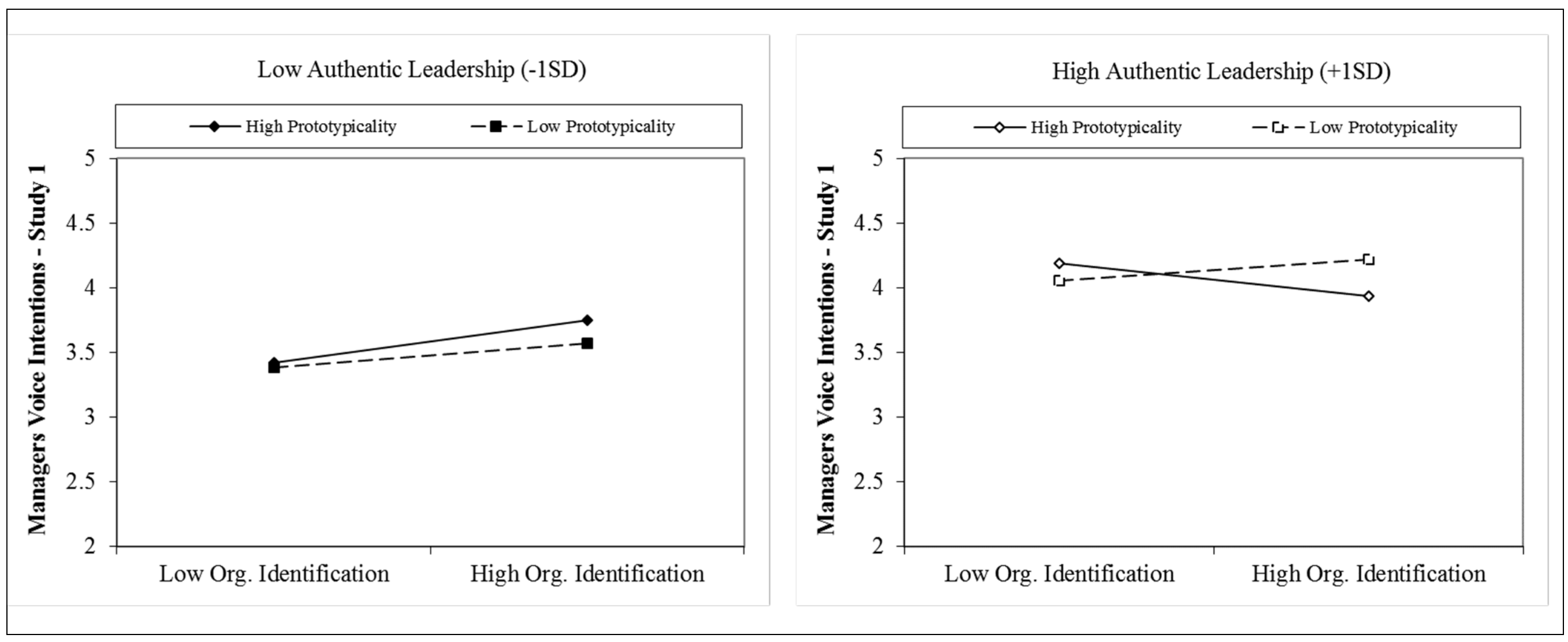

Figure 4a. Three-way Interactive Effect of Authentic Leadership, Managers' Organizational Identification and Leader Prototypicality over Prohibitive Voice (Study 1) 


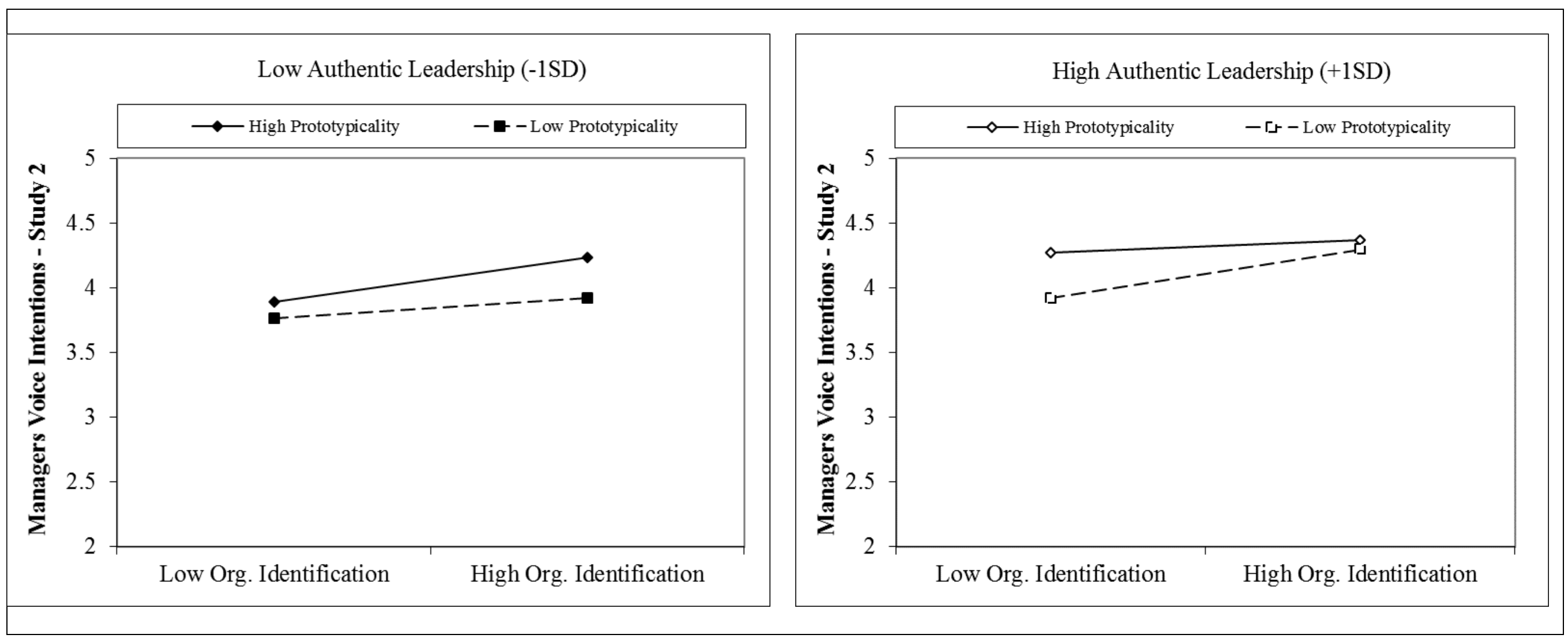

Figure 4b. Three-way Interactive Effect of Authentic Leadership, Organizational Identification and Leader Prototypicality over Prohibitive Voice (Study 2) 


\section{Appendix 1}

\section{Survey Scenario}

The scenario described a situation in which a leader had to decide between speaking up about a problem or remaining silent. The dilemma was that remaining silent would threaten the fictive organization "EONROTH" as whole and even stakeholders, for example customers. However, speaking up would threaten team members' efforts and the interests of superiors and colleagues.

The exact wording of the scenario was "Now, please imagine you realize that a product or a service of EONROTH provides the risk of not meeting the customers' expectations. In the long run, it could even harm customers or the reputation of your organization. The team has worked very hard on this product for the last years and even accepted overtime hours. The team would definitely be disappointed if you do not release it. Moreover, your board of directors and maybe your team too, hope that this product or service will carry a yield for the organizations in the years to come." 